\title{
Immunological Variations in Epileptic Children
}

\author{
Sanjeev Kumar ${ }^{1 *}$, Vinod Kumar ${ }^{1}$, D. C. Jain ${ }^{2}$, R. Mittal ${ }^{3}$ \\ ${ }^{1}$ Department of Physics, Medical Physics Research Laboratory, D.A.V. (P.G.) College, Muzaffarnagar, India \\ ${ }^{2}$ Department of Neurology, Safdarganj Hospital, New Delhi, India \\ ${ }^{3}$ Department of Mathematics, Shri. K.K. Jain College, Khatauli, India \\ Email: *sanjeev1962kumar@yahoo.co.in, *sanjeev1962kumar@rediffmail.com,neuro_dc@hotmail.com, \\ reena_math@rediffmail.com
}

Received September 30, 2012; revised November 3, 2012; accepted November 12, 2012

\begin{abstract}
Epilepsy is one of the most frequent neurological problems. Despite of the advances and improvements in treatment of seizure disorders, immunological alterations such as immunoglobulins and complements have been measured. The levels of $\operatorname{IgG}$ in epileptic patients are found to be higher than controls. The levels of $\operatorname{IgA}, \operatorname{IgM}, C_{3}$ and $C_{4}$ were found to be lower in all the controls. Student's t-test were also applied. Multiple and regression analysis, have been also carried out. A trend $R_{M \cdot A G}>R_{G \cdot M A}>R_{A \cdot G M} \& r_{G M \cdot A}>r_{M A \cdot G}>r_{M \cdot A G}$ has also set up in the present study. An alteration in the immune mechanism of epileptic patients is required. Ketogenic diet may be given and the balance of trace elements like Na, K, $\mathrm{Zn}, \mathrm{Fe}, \mathrm{Ca}, \mathrm{Mg}$ and $\mathrm{Cu}$ may be maintained to alter the immune mechanism of the epileptic patients. Green leafy vegetables may be given to the patients to control the seizure. Immunity is related with the food we eat. By adjusting the immunity with proper diet the severity of epileptic attack or any disease may be reduced.
\end{abstract}

Keywords: Epilepsy; Immunoglobulins; Central Nervous System; Complements

\section{Introduction}

Humoral immunity is manifested by the production of antibodies. The antibodies are special chemical substances that react against foreign substances. Antibodies are called as immunoglobulins. Immunoglobulins are serum proteins, which possess antibody activity and which are classified according to the antigens and stimulate their production such as $I g A, I g G, I g M, I g D$ and $I g E$. In order for antibody to have a cytotoxic effect, an extra substance is required called complement and much has yet to be discovered about its nature and precise functions. The presence of antigens in the body stimulates certain types of defense cells to produce antibodies. Humoral immune response depends on a group of small lymphocytes called B-lymphocytes (B-cells). B-cells originate in bone marrow and travel directly into lymphoid tissues. Cell mediated immunity is directly expressed by certain type of defense against the antigens. These cells are also lymphocytes, but with a slightly different maturation having the influence of the thymus gland. These are called Tlymphocytes in contrast to B-lymphocytes, which produce humoral immunity.

T-cells also originate in bone marrow but unlike Bcells, they do not travel directly into lymphoid tissues, but first enter the thymus where they undergo a condi-

${ }^{*}$ Corresponding author. tioning process, hence the name thyms dependent lymphocytes. After leaving the thymus thus migrate to special regions known as thyms-dependent areas, namely the paracortical area of lymph.

It was thought that the central nervous system (CNS) is inaccessible to the immune system in human beings. The concept of immune privilage originated from four historical findings. Ehrlich [1] reported some of the main findings regarding parenterally administration of aniline dyes, which stained almost all body tissues except CNS. Due to this magnificant observation concept of blood brain barrier (BBB) physiologically separated central nervous tissue from the systemic circulation and systemic immune response.

Murphy and Sturm [2] have studied mouse sarcoma tissue, which was found not to be rejected implantation into rat brain. It implies that the CNS was exempt from the immunological processes responsible for graft rejection. Sabin [3] studied the absence in brain of direct lymphatic drainage and by implication of circulating lymphocytes-depriving the CNS of an apparently essential requirement for immune response generation, which provide an argument in favour of immune isolation. Ediden [4] has reported findings regarding normal nervous tissue, which was not to express major histocompatibility complex (MHC) antigens. It exempts the brain from participation in cell-medicated immune reactions. 
Immunocompetence of CNS was under some objections. Adverse immune reactions were recognized and reported in the literature. A rabies virus vaccine pricipitated with a small number of patients and a neuroparalytic illness was found to constitute an autoimmune hyper sensitivity reaction; and an acute disseminated CNS inflammatory disorder precipitated by inoculation with nervous tissue. These findings and favourable outcome of infectious encephalitides and the brisk cerebrospinal (CSF) Pleocytosi, which accompanies brain infection, indicate that immune responses can and must be generated within the brain.

The major role of immune system in the CNS is to protect the host against infection and perhaps also neoplasia. It has been seen that three steps in the protection are first identification of the invaliding microbe or tumor clearance and finally memory for the pathogen so that the immune system may equipped to defend against repeated infections.

CNS and immune system should not be separated but rather as elements of a vast commutation system in which they may exchange information both via an atomic connections and though the hormones and mediators released by hypothalamopituitary axis [5-8]. It is well established that any excessive or uncontrolled immune reaction may be expected to interfere with the brain's physiology. We may say that any neurologic dysfunction carries the risk of disturbing the delicate equilibrium of the immune network conversely it is true.

This statement is helpful to provide the rationale for the therapeutic concept of immunomodulation of certain immune disorders [7]. Abnormalities of the immune system are indeed increasing number of neuropathies as well as in some psychiatric syndroms [6,7].

Pharmocologic manipulations of immune pathologies such as rheumatoid arthritis systemic lupus erythmatius etc., by means of neurohormones have been routinely performed.

The process of inflammations increases vascular permeability and allows anti body, complement and other proteins to pass out the circulation and enter the extravaseular space. It may also induce inflammatory cells, including lymphocytes, to cross the vascular endothelium and accumulate in the tissues. Total net effect is to deploy all the resources of the immune system at the site of injury. Cells antibody and complement leave the blood and go into action where the demand is high. It may be in the affected tissue outside the vessel wall.

The effect is to abrogate in CNS, if only temporarily, its isolation from the immune processes of the body. The barrier, which excludes plasma proteins from the brain breaks down, allowing antibody to enter the extra vascular space. The amount of protein in CSF increases and with it the level of immunoglobulin may also change.
Immuno competent cells enter the CNS. CNS now becomes capable to generating an immune response [9]. Antibody, which synthesized locally, adds to that leaking from vessels and increased the level of immunoglobulin. This is a complete reversal of the normal stage and the antibody levels very low. Lymphoid cells may be excluded. Inflammation has three main consequences. It allows lymphocytes and antibody forming cells to enter the CNS and immunoglobulin to be synthesized in the brain and spinal cord.

Lymphocytes accumulate in the CNS in so many inflammatory diseases. They enter from the blood stream, which passed out of the capillary wall between the endothelial cells through altered tight junctions by a process of emperopolesis. Emperopolesis is a process, which describe the behaviour of lymphocytes in tissue culture. They appear to move about inside the cytoplasm of the sebbile cells.

Electron micrograph of the brain shows then travering the endothelial cells of the cerebral capillary. They are enveloped by the plasma membrane and completely surrounded by the host cell, only to extrude on the other side.

Lymphocytes and macrophages entering the CNS accumulate in the Virchow-Rabin space. A sharply demarcated perivascular cuff off inflammatory cells. They may also extend out into the neurophil infiltrating the parenchymal tissue. Similar peri vascular accumulation can be seen in menings large numbers of lymphocytes, which may enter the subarchnoid space.

The permeability of the cerebral vessels to protein may increase as a result of inflammation. The antibody enters the extravascular space. The vascular permeability changes are often transitory and disappear, but the cells continue to enter from the circulation. In the later stages of the disease the vessels may be impermeable to protein although surrounded by densely packed cuff off mononuclear cells. Oldstone et al. [10] have studied immunofluorescence technique and reported that albumin is a small molecule and convenient as a marker, but larger protein such as fibrinogen leak from vessel as well. It may be deposited as fibrin in and around the cerebral vessel. Immunoglobulin and complement $C_{3}$ also pass out of the vessel and diffuse into the brain parenchyma.

A vascular leak directly may be seen in human diseases. It changes the composition of CSF. The inflammation may increase the total protein level. This level is found normaly (200 - 400) $\mathrm{mg} / \mathrm{l}$ and raise in many neurological diseases. CSF protein level is not a measure of the efficiency of the blood brainbarrier (BBB).

Many proteins may have an involvement in the process of fluctuation of their levels independently. It has been seen that some of them may be produced with in the nervous system. Many of proteins may be released from damaged brain tissue. Immunoglobulin may be synthe- 
sized within the CNS and boost up the CSF protein level without vascular leak. Albumin is a good marker, which drives from plasma. It is synthesized in the liver and measured by radial immuno diffusion technique. It is found with high concentration in CSF.

It has been reported that in many inflammatory diseases of the nervous system, lymphocytes enter the brain and cord. Both T and B cells may appear in CSF in large amount. It is seen that the percenatage of $\mathrm{T}$ cell is increased in many specific conditions compared with that in the blood and the percentage of B cells is reduced reciprocaly.

In acute and chronic infections B-lymphocytes may differentiate into plasma cells. This transformation may be observed in CSF, where all the cells of the lymphoid series may be found, ranging from small, medium and large lymphocytes and immunoblasts to nature plasma cells.

In many neurological diseases the immunoglobulin level of CSF is found to be higher. This feature is often disproportionate to the rise in total protein and it is due to antibody synthesis in the nervous system. It is very well known that the percentage of immunoglobulin in CSF may be raised in many diseases.

It has been found that the proportion between the concentration of a protein in the serum and the CSF remains the same, irrespective of the serum level. Serum $\operatorname{Ig} G$ and the albumin ratios remain constant and their quotient is also constant as well This has been designated the $I g G_{\text {Index }}$.

$$
I g G_{\text {Index }}=\frac{I g G_{\mathrm{CSF}}}{I g G_{\text {Serum }}} \div \frac{A l b_{\mathrm{CSF}}}{A l b_{\text {Serum }}}
$$

From the equilibrium position reached between CSF and plasma we can calculate the proportion of immunoglobulin entering from the circulation.

The amount of $I g G$ entering from plasma as exudates or transudate cannot be calculated directly. We can get some useful informations from levels of $\mathrm{Ig} G$ and albumin in the CSF and plasma.

$$
\begin{aligned}
I g G_{\text {Synthesis }}= & {\left[\left(I g G_{\mathrm{CSF}}-\frac{I g G_{\text {Serum }}}{369}\right)\right.} \\
& -\left(A l b_{\mathrm{CSF}}-\frac{A l b_{\text {Serum }}}{230}\right) \\
& \left.\times\left(\frac{I g G_{\text {Serum }}}{A l b_{\text {Serum }}}\right) \times 0.43\right] \times 5 \\
I g G_{\text {excudate }} & \left(A l b_{\text {CSF }}-\frac{A l b_{\text {Serum }}}{230}\right) \times\left(\frac{I g G_{\text {Serum }}}{A l b_{\text {Serum }}}\right) \times 0.43
\end{aligned}
$$

where $I g G_{\mathrm{CSF}}$ is equal to the levels of $\operatorname{IgG}$ measured in CSF $I g G_{\text {Serum }}$ is equal to the levels of $I g G$ measured in Serum $A l b_{\mathrm{CSF}}$ is equal to the levels of albumin measured in CSF $A l b_{\text {Serum }}$ is equal to the levels of albumin measured in serum

We assume that the plasma contribution is made up of two separate elements the normal transudate across the blood brain barrier, supplemented by an exudate or inflammatory leak at the stage of breaking of BBB. we have a situation like

$$
\begin{aligned}
I g G_{\text {Synthesis }} & =I g G_{\mathrm{CSF}} \\
& -I g G(\text { transudate })-I g G(\text { exudate })
\end{aligned}
$$

The amount of $I g G$ in the exudate is calculated from the albumin levels in CSF and plasma. It is assumed that these two proteins cross the barrier in a fixed quotient directly related to serum concentration:

$$
\frac{\operatorname{Ig} G_{\text {Serum }}}{A l b_{\text {Serum }}}
$$

and inversely to molecular weight

$$
\frac{69000}{150000}=4.3
$$

Albumin in the exudates is estimated by subtracting the amount in the transudate

$$
\frac{A l b_{\text {Serum }}}{230}
$$

From the total, allowing the $I g G$ in the exudate to be calculated as follows:

$$
\begin{aligned}
& I g G_{\text {excudate }} \\
= & \left(A l b_{\mathrm{CSF}}-\frac{A l b_{\text {Serum }}}{230}\right) \times\left(\frac{I g G_{\text {Serum }}}{A l b_{\text {Serum }}}\right) \times 0.43
\end{aligned}
$$

\subsection{Tolerance and Autoimmunity in the Nervous System}

It was believed that only foreign proteins are considered true antigens. Ehrlich [1] had introduced horror autotoxicus. Due to this fact, it is possible for body, which may generate antibodies against itself. Autoimmunity suggests that an appropriate immune response is directed against a normal tissue component and leads directly to disease in the absence of persisting infection. Microbes are responsible for autoimmunity. If autoimmunity persists during the disease it is inappropriate to term the disease autoimmune.

The distinction between autoimmune response triggered by an infection and inflammation directed against a persistent microbe has been studied by Miller et al. [11]. $\mathrm{T}$-cell reactivity against the major encephalitogenic pep- 
tides of proteolipid proteins and myelin basis protein.

\subsection{Mechanism of Auto Immunity}

Auto immunity may be initiated in the following ways:

1) A self-antigen may be modified and appear as foreign.

2) Ignorant clones may be educated. Microbes may cross-react with self antigens to which the immune system is ignorant. Epitope is at low concentration perhaps. A cross-reacting microbes present in heavy numbers than the original value of antigen and is able to activate and prime T-cells. Once so primed, the original antigen is sufficient to perpetuate the inflammation.

3) Removal of suppression of auto reactive processes. Microbes might cross-react with idiotope and so disrupt the anti-idiotypic network in favour of immunity. The normal regulatory mechanisms of the immune response should restore self tolerance after the initiation of autoimmunity. The maintenance of autoimmune disease must require either multiple rounds of autoimmunity to different self-antigens or a single autoimmune response that is perpeturated by defective regulation. A different form of altered immune regulation is an abnormal cytokine response.

Majority of autoimmune processes are driven by Tcelluler processes. Important exceptions are the anti acetyl choline receptor antibody of mysthenia gravis and antibodies against epithelial adhesion molecules in the bullous skin disease. In the CNS, the pathogenicity of autoantibodies, such as those associated with the paraneoplastic syndrome or stiff man syndrome is not clearly well documented.

\subsection{Antigen Specific Tolerance to Unknown Auto Antigens}

It has been seen in many autoimmune disease of the nervous system, driving auto antigen is not known. A treatment is required that makes no assumptions about the provoking antigen and induces antigen -specific tolerance. A short pulse of antigen nonspecific therapy set up a sequence of events leading to the perpeturation of antigen, specific tolerance. This strategy has been used to justify the use of humanized monoclonal antibody. The earlier work on complement deficiency of specific complement components is responsible for a couple of diseases. It is very important to remember that this is similar to the disorders, which occur with selective deficiencies of the immune system [12].

There are two types of deficiencies of complements: hereditary and acquired.

Acquired deficiencies persist over a long periods and also become causative factor for certain disease. The complement system consists of a series of proteins, there are only a handfull of proteins in the complement system, floating freely in the blood. Complements are created in a person's liver and are activated by the work with antibodies. Complement cause lysing or brusting of cells and signal to phagocytes that a cell needs to be removed.

Complement are sequentially reacting proteins on activation these proteins mediate a number of biological reactions significant to host defense against bacteria, viruses and other injurious stimuli. Antigen-antibody complexes, bacterial and plant polysacharides and microbial and tissue enzymes initiate the activation. Biological activities mediated by the activated complements proteins or by their fragments include increased capillary permeability, chemotaxis of leukocytes, enhanced phagocytosis, retention of leukocytes at the site of tissue injury and cytolysis. The most thoroughly studied biological complement system has 18 proteins. These are in higher concentration in plasma. The basic role of complement system is mediation of host defense against microbial infection. This goal is full-filled during activation of complement by the elaboration of peptides, larger protein fragments and multimolecular complexes that opsonize and lyse the activating target; induce chemotactic, secretory and metabolic response of leukocytes and alter vascular permeability. These activities constitute an inflammatory response. Fearon, D.T. [13] has given information regarding complement system and he suggested that this complement system is the most complex of the several protein activation system in blood, but this complexity can be reduced by considering the system to be comprised of there functional division: two pathways for activation the classical and alternative pathways and a common effector sequence to which the activating pathways are directed and from which are derived many of the biological activities of complement. Molecular weight that of complement $C_{3}$ is 185,000 while that of complement $C_{4}$ is 180,000 . Serum concentration of complement $C_{3}$ and $C_{4}$ are $1500 \mu \mathrm{g} / \mathrm{ml}$ and $400 \mu \mathrm{g} / \mathrm{ml}$.

Some of the important phenomena have been studied by Valanakis, J.E. [14] occurring during activation of the complement sequence and these are related to

1) Acute inflammation.

2) Cell killing namely, which has the following procedure:
a) Increased vascular permeability;
b) Chemotaxis of leukocytes;
c) Enhanced phagocytosis;
d) Membrane damage.

The limited proteolytic reactions, which characterize the complement system, are essentially not reversible. These reactions lead to cleaved proteins, which are recognized by the body as altered or foreign. These proteins are rapidly cleared from circulation. Despite compensatory increase in synthesis the result is usually a decrease 
in plasma levels. Thus, an ongoing immunologic event, which is activating the complement system in vivo is likely to generate a decrease in plasma levels of these proteins. Conversely, the abatement of the complement activating stimulus may be paralleled by a reform of the complement levels toward normal has been reported by Stein, J.H. [15].

The main mediator mechanism of humoral immunity is the complement system. It is an important and essential mechainsm for the destruction both of foreign organisms and immunocomplexes in the presence or absence of specific antibodies. It is a double edged sword and may also destroy host tissue. Fishman R.A. [16] reported that CNS is immunologically unusual tissue do to the presence of BBB. It may exclude many components of the immune sustem like antibodies and complement system. These studies imply a suppressive environment for immune reactivity in the CNS. Monocytes or macrophases are the important and major extrathepatic sources of complement components. Microglia or astrocytes have been suspected to be the cells which produce complement proteins in brain such as $C_{3}$.

Milica, T.C. et al. [17] have been studied the role of complement system. This system does not support in chronic and neurodegenerative disorders. There are two separate complement pathways active by distinctly deferent classes of activators, specific; identification of complement factors in CSF promises to be diagnostic not only of complement activation but also of the mode of activation. Epilepsy is a common neurological problem, which has occupied clinicians for many centuries. It has been noticed that there is strong evidences for polygenic predisposition and in some of cases genetic factors causing epilepsy. Toxins, which is environmental factor plays an important role in some cases of epilepsy. Immunological mechanisms have also been implicated as aetiology of epilepsy

Some clinical observations show that the aberrations of immunologic system may be associated with untreated epilepsy and pharmacologically treated epileptic patients. The nervous system and the immune system posses a number of interesting similarities. Both of these use welldefined, specialized cell types that communicate through a variety of intercellular mechanisms and develop a specific response to external stimuli. These two demonstrate memory and adapt to historical experience. Dysfunction in the brain can lead to seizures. It can lead to autoimmunity [18] in the immune system.

We may see many examples of the direct interactions of the immune system and the brain in patients with epilepsy. There is an increased incidence of epilepsy after stroke, trauma, or infection. These environmental conditions may release brain antigens, stimulate cytokine release, and result in immune activation. Some of the proteins with epilepsy well have a transient worsening of their symptoms with inter current illness. Such worsening does not necessarily imply a CNS infection, but rather an example of the brain's response to active immune surveillance. Epilepsy is primarily a paroxysmal disorder of brain function. The brain has a special relationship with the immune system. An understanding of this relationship is essential to realize some of the immunological problems meet in epileptic patients.

Bouma, P.A. [19] suggested that $\operatorname{IgA}$ deficiency is found in most of the epileptic patients and it goes upto $25 \%$. Golamali, Y.P. [20] studied immunoglobulins in idiopathic generalized tonic-clonic epilepsy and found that the changes in serum level of auto antibodies in patients were found to be very high. The above-mentioned abnormalities are associated with both seizure disorders per se and also anti epileptic drugs $\left(\mathrm{AED}_{\mathrm{S}}\right)$. Baziel, G.M.V.E. et al. [21] have reviewed and studied immunoglobulin levels in epilepsy. They have reported that comulative meta-analysis of the earlier studied is not possible due to lack of controlled studies. Savory, J, et al. [22] have studied cerebrospinal fluid levels of $\operatorname{IgG}, \operatorname{IgA}$, and $I g M$ in neurological disorders such multiple sclerosis, subacute sclerosing, panencephalities bacterial meningitis, viral meningitis, Guillian-Barre syndrome and some miscellaneous disorders. They have reported finding such as elevation of $\mathrm{IgG}$ levels in multiple sclerosis goes upto eighty eight percent. Masi, M., et al. [23] have studied immuno suppression by Phenytoin and reported the findings as serum. Immunoglobulin levels were observed in $\mathrm{mg} / \mathrm{dl}$ unit. The level of $\operatorname{IgM}(95 \pm 0) \mathrm{mg} / \mathrm{dl}$ and $\operatorname{IgG}$, $(1180 \pm 0) \mathrm{mg} / \mathrm{dl}$. Their findings reinforce the suspicion that phenytoin may cause severe impairment of both humoral and cellular immunity. Bassanini et al. [24] have examined serum immunoglobulins in some epileptic patients and compared with controls with the aim to explore whether the previously reported alterations of Ig concentrations in epileptic patients are due to anticonsultant therapy or due to epilepsy itself. Walker [25] proposed immunological approach for future work on epilepsy; no subsequent explanation for epileptogensis in immunological terms has been reported. Some of the earlier investigators [26] have proposed that the alterations in electrical discharges, which comprise epilepsy could be the result of an autoimmune response directed against transmitter receptor sites at synapses. Most of the familiar types of epilepsy have been attributed to be associated with tissue damage. Amman and Hong [27] have found that low serum $\operatorname{IgA}$ concentration is frequently associated with low IgA levels in secretions. Slavin et al. [28] concluded that the alterations of immunoglobulin levels in epileptic patients are not directly related to medicament effect, but could be secondary to epilepsy per se; principally in these patients with mental disorders. Some of cases of epilepsy may have an immunodeficiency basis [29]. Grob et al. [30] have found that the serum $\operatorname{IgA}$ 
reduced in some patients on long term oral medications with hydantion and also many other patients were having immunologic deficiency. There is no well defined constituent defect in cellular immune function in all patients with IgA deficiency. Aman and Hong [31] suggested that the maintenance of cellular immunity be taken as one of the criteria for diagnosis for the disease.

Yabuki and Nakaya [32] observed that a significant number of patients, had slightly low serum IgM level among epileptic patients on oral antiepileptic drugs. Conversely, there were also many patients, who had high IgG levels above the normal range. Phenytoin was the only drug with which these patients of abnormal serum immunoglobulin levels were commonly mediated. No such immune abnormalities were observed by them in some patients not treated with oral antiepileptic drugs. Allansmith et al. [33] reported that the serum concentration of immunoglobulins changes insignificantly within individuals. Anderson and Moseklide [34] exhibited that immunological abnormalities do not develop in all patients receiving long term anti convulsant therapy and it is possible that genetic predisposition is of importance in the development of Ig deficiency and auto immunity in drug-treated epileptics. Matsuoka et al. [35] demonstrated that the cellular events involved in IgA deficiency in epileptic patients were heterogeneous but were similar to those involved in primary IgA deficiency. This might point out that some of the patients studied were not induced by anti convulsants. The reason of this heterogenity with regard to defects in terminal differentiation of IgA-B cell is not known. Probable factors are kinds of drugs used, the type of epilepsy and genetic factor [36] involved in the development of the disease. The comparative study of drug-induced IgA deficiency and selective $I g A$ deficiency can throw light on the reason why the defective $I g$ class is $I g A$, not $I g G$ or $I g M$ in the epilepsy.

Dashora, U.K. et al. [37] have reported some abnormalities in the immunoglobulins of the epileptic patients. In the untreated epileptic patients, the main serum values of $\operatorname{IgA}, \operatorname{IgM}$, and $\operatorname{Ig} G$ have been found to be lower than the controls. However the observed differences have not been found to be statistically significant. Individual variations have been noticed. Aarli, J.A. et al. [38] have studied immunological aspects in epilepsy and reported their finding as epileptogenic activity can be provoked in animals by topical application on the cerebral cortex of antiserum to brain tissue. Some of the epileptic patients may have IgA deficiency. This deficiency may be caused by antiepileptic drugs or may be associated with the condition of epileptic patients. A few epileptic patients develop autoimmune disorders when given antiepileptic drugs. Aarli, J.A. [39] has also worked on the same problem of immunological aspects in epilepsy and found that these aspects of epilepsy are not confined to the depressive effect of some antiepileptic drugs upon the immune system. They also comprise factors relevant to the pathogensis of some forms of epilepsy as well as variety of clinical manifestations met in some epileptic patients. Al-Hakeim, H.K. [40] studied serum cortisol immunoglobulins \& some complements among depressed patients and found a slight positive correlation was observed between cartisol verses $I g G$ in depressed patients and it was absent in healthy controls. Mirdha, B.R. [41] studied status of toxoplasma gondii infection in the etiology of epilepsy. It has been reported that seropositivity was higher in children compared to adults. The detection of antibodies to toxoplasma in sera from patients suffering from recurrent unprovoked seizures. Riddoch, D. et al. [42] have measured immunoglobulins in CSF in different neurological disorders. They have reported as the levels of $I g G$ were found to be higher in multiple sclerosis. $I g G$ level may be a predictor as good indicator in multiple sclerosis Callenbach, P.Mc. et al. [43] have measured immunoglobulins in children with epilepsy. They have reported that valproic acid used as a monotherapy for patients. The levels go down to normal values. Humoral immunity has already altered in children with epileptic seizures. Ashrafi, M. et al., [44] have studied the effect of antiepileptic drugs on serum immunoglobulin levels in children. They have reported that the changes in serum immunoglobulin concentrations in patients treated with anti convulsant medicines deserve consideration, because of their frequency of attacks and possible clinical repercussions. The changes in immunoglobulin level can be due to the consumption of antiepileptic drugs. IgA serum concentration with carbamazepine has a decreasing trend.

Bostantjopoulou. S., et al. [45] have studied immunological parameters in patients with epilepsy. They have reported their findings as levels of $\operatorname{Ig} G, \operatorname{IgM}$ and $\mathrm{Cu}$ were decreased. The levels of $I g G$ and $I g M$ were found to be higher and the levels of $\mathrm{Cu}$ decreased after administration of Carbamazepine and Valproate respectively. The findings indicate that there is defective immune mechanism in epilepsy it should be modified accordingly.

De Ponti, F., et al. [46] have studied immunological adverse effects of anti epileptic drugs. It has been well established that certain adverse reactions to antiepileptics may have an immunotoxological origin e.g. lymphadenophathy, pseudolymphoma and systemic lupus erytheomatosus (SLE). They have also reported that the immunotoxic potential of anticonvulsants appears very low and the monitoring of $I g$ levels not required in patient with known immune defects. Basta-Kaim, A. et al. [47] have also studied the effects of antiepileptic drugs on immune system. They have reported that classical antiepileptic drugs affect peripheral immunological parameters. 
Phenytion, Carbamazepine both attenuate humoral and cellular response. Phenytion, Carbamazepine and Valproate show an immunosuppressive trend and inhibit protein synthesis in lymphocytes decrease $\operatorname{IgA}$ and induce changes in $I g G$ and $I g M$ plasma levels. Studies on chornic administration of traditional and new antiepileptic drugs on immune system activity are clearly restricted and warranted. Ranua, J. et al. [48] have also reported their findings on $\operatorname{IgA}, \operatorname{Ig} G$ and $I g M$, concentrations with epileptics patients. They have reported that no difference in serum IgG and IgM concentrations were found between patients and healthy controls. The low value of serum IgA levels were reported on Phenytoin medications. This medication may have characteristics of immunological effects in patients of epilepsy. Baziel, G.M.V.E. et al. [20] have studied immunoglobulin treatment in epilepsy with a detailed review work. During the immunological treatment mean clinical seizure were reduced and mean EEG improvements seen. Bardana, E.J. et al. [49] have studied effects of Phenytoin on man's immunity with reference to immunoglobulin and complement and some other factors related to antinuclear antibody. They have reported that the serum $\operatorname{Ig} A$ concentration was high. A decrease of $\operatorname{IgA}$ level was also observed with the Phenytoin treatment. Minor decrease in serum $\operatorname{Ig} G$ and IgM were reported. Serum IgD and complement were unaffected. Antinuclear antibodies were also observed as same as before the Phenytion treatment. Vezzani, A. et al. [50] studied innate immunity and inflammation in temporal lobe epilepsy with new emphasis of complement activation. They have given idea of complement and it is a double edge sword with the capacity to harm as well as heal. The general role for complement in neurodegenerative processes comes from the evidence of chronic complement activation and synthesis in different neuropathological conditions. There is a prominent activation of the complement cascade during the epileptogensis phase in human also. Aronica, E. et al. [51] have studied complement activation in experimental and human temporal lobe epilepsy with the findings of persistence of complement activation could contribute to a sustained inflammatory response. It could be helpful in destabilizing neuronal networks involvement.

Price P. et al. [52] have studied cerebrospinal fluid (CSF) complement proteins in neurological disease. They have shown that the CSF levels of $C_{3}$ and $C_{4}$ were similar to controls. The levels of $\operatorname{Ig} G$ were very high. The roles of local production and consumption of complement protein and damage to the blood brain barrier were also taken into consideration for the data analysis. Basaran, $\mathrm{N}$. et al. [53] have studied humoral and cellular immune parameter in untreated and Phenytoin or Carbamazepine treated epileptic patients. They have reported their findings as the levels of $\operatorname{Ig} M$ and $C_{3}$ were significantly higher in untreated epileptics rather than healthy controls. IgM levels were lower in Carbamazepine treated epileptic patients. The levels of $I g A$ and $I g G$ were lower than healthy controls with the application of Phenytoin treatment. Oettinger, B., et al. [54] have studied antiepileptic drug levels and side effects in man. They have succeceded in reducing the frequency of attack by Phenobarbital. Side effects of the drug were completly disappeared. Gilhus, N.E. et al. [55] have studied respiratory disease and nasal immunoglobulin concentrations in the patient of epilepsy treated with Phenytoin. They have reported negative findings such as no difference found with $I g A$ deficiency in serum and nasal secretion. $I g G$ and $I g M$ levels in nasal secretion do not show any direct relationship to the frequency of respiratory symptoms. The main aim of research work is to throw light on some of the aspects of epilepsy with special reference to immunology. Immunological parameters play an important role in understanding the causative mechanisms for this typical brain syndrome.

We wish to determine the levels $\operatorname{IgA}, \operatorname{IgG}, \operatorname{IgM}, \mathrm{C}_{3}$ and $C_{4}$ in epileptic children. Students "t" test will also be applied for the statistical point of view. Multiple correlation coefficient analysis will also be carried out.

\section{Materials and Method}

\subsection{Selection and Exclusion of Patients}

We have selected epileptic children whose aged group has a range of zero to twelve years. The patients were on standard medicines. We did not select above this age group. Blood samples of epileptic patients were collected from the Department of Neurology, Safdarjang Hospital, New Delhi 110016 after the approval of ethical committee of the hospital. 10 milliliters freshly drawn blood from each patient was collected in clean and dry test tube without any anti-coagulant. The test tube was kept for 45 minutes at room temperature $\left(22^{\circ} \mathrm{C} \pm 2^{\circ} \mathrm{C}\right)$ for the formation of clot. Sera of different patients were separated by centrifugation at 1500 r.p.m. upto 15 minutes and were collected in screw capped test tubes.

The immunological parameters $\left(\operatorname{IgA}, \operatorname{Ig} G, \operatorname{Ig} M, C_{3} \&\right.$ $C_{4}$ ) were quantitated by using singles radial immunodiffusion method of Mancini et al. [56] using commercially available antibody-agar plates. The plates were standardized with purified immunoglobulins. The purpose of this study is to measure serum levels of immunoglobulins (IgG, IgA \& IgM) and complements $\left(C_{3} \& C_{4}\right)$. These measurements aid in the clinical diagnosis, assessment of disease activity, response to treatment, and follow-up in patients with various clinical conditions. Measurements of immunoglobulin A $(\operatorname{IgA})$ and immunoglobulin $\mathrm{M}(\operatorname{Ig} M)$ aids in the diagnosis of abnormal protein metabolism and the body's lack of ability to resist infectious agents. Mea- 
surements of $\mathrm{IgG}$ aids in the diagnosis of autoimmune diseases, sarcoidosis, chronic liver disease, chronic and recurrent infections, lymphoid malignancies, multiple myeloma and severe and variable immunodeficiencies.

\subsection{Statistical Analysis}

We have used a regression analysis regarding the validity of our data. A multiple correlation coefficients analysis has also been applied to the study Regression analysis with different equations has also applied to calculate multiple correlation coefficient.

1) Regression analysis is used to find equations that fit data. Once we have the equation, we can use the statistical model to make predictions. One type of regression analysis is linear analysis. When a correlation coefficient shows that data is likely to be able to predict future outcomes and a scatter graph of the data appears to form a straight line, statisticians may use linear regression to find a predictive function. The equation for a line is

$$
y=m x+b
$$

We can take data to calculate linear regression, and we can find the regression equation as

$$
y^{\prime}=a+b x
$$

is a way to describe a relationship between two variables through an equation of a straight line, called line of best fit, that most closely models this relationship (Figure 1). Linear Regression Formula can be used to derive the equation for the line of best fit:

$$
Y=a+b x
$$

where

$$
b=\frac{\sum_{i=1}^{n} x_{i} y_{i}-n \overline{x y}}{\sum_{i=1}^{n} x_{i}^{2}-n \bar{x}^{2}}
$$

and

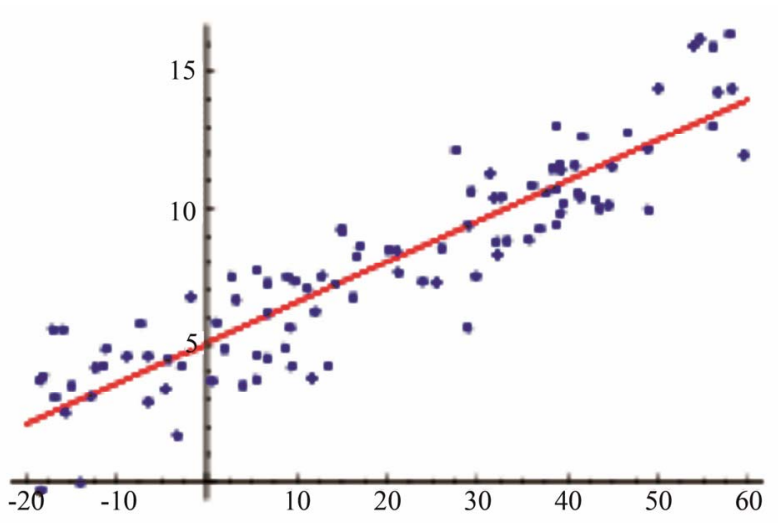

Figure 1. Simple linear regression.

$$
a=\bar{y}-b \bar{x}
$$

2) The Simple Multiple Correlation Coefficient $(R)$ is a measure of the strength of the association between the independent (explanatory) variables and the one dependent (prediction) variable. Interpretation of $R$ can be very well explained with the strength of the association: The strength of the association is measured by the sample Multiple Correlation Coefficient, $R$. $R$ can be any value from 0 to +1 . If it is closer $R$ and is equal to one, the linear association will be stronger. If $R$ to zero, then there is no linear association between the dependent variable and the independent variables. Unlike the simple correlation coefficient, $r$, which tells both the strength and direction of the association, R tells only the strength of the association. $\mathrm{R}$ is never a negative value.

This can be seen from the formula below, since the square root of this value indicates the positive root.

$$
R=\frac{\sqrt{r_{y x_{1}}^{2}+r_{y x_{2}}^{2}-2 r_{y x_{1}}\left(r_{y x_{2}}\right)\left(r_{x_{1} x_{2}}\right)}}{\sqrt{1-r_{x_{1} x_{2}}^{2}}}
$$

\section{Results}

Experimental findings along with work carried out by researchers on different modes of analysis and diseases are tabulated in Tables 1-3. Statistical analysis like regression analysis and multiple correlations were also tabulated in Tables 4-7.

We have shown our data on the basis of experimental procedure of Radial immuno diffusion technique of Mancini, G. et al. [56]. Data reveal that the levels of $C_{3}$ do not have any deflection from the normal healthy controls. The levels of $C_{4}$ were lower about $20 \%$ and levels of $I g A$ and $\operatorname{Ig} M$ were found to be lower with the normal data. The higher values of $I g G$ show that the patients may get some infection, which may be a causative factor in this disease. Recently nervous system disorders have been shown to be associated with autoantibodies. It is well recognized that the epileptic children producing one autoantibody have an increased likelihood of having other autoantibodies. It is possible that the epilepsy represent the first manifestation of the syndrome itself. The antibodies themselves may be implicated directly triggering the epilepsy.

\section{Discussion}

Central nervous system (CNS) is relatively isolated from systemic immune response in the absence of disease. There is no mechanism found for antibody production within the normal condition of CNS. This system has been described as an immunologically privileged site due to paucity of normal immune surveillance. If a virus penetrates the blood brain barrier (BBB) that exclude 
Table 1. Values of $C_{3}, C_{4}, I g A, I g G$ and $I g M$ measured in epileptic patients and normal healthy controls are presented.

\begin{tabular}{|c|c|c|c|c|c|c|}
\hline S.No. & Types of Samples & $C_{3} \mathrm{gm} / \mathrm{l}$ & $C_{4} \mathrm{gm} / \mathrm{l}$ & IgG gm/l & $\operatorname{Ig} M \mathbf{g m} / \mathbf{l}$ & $\operatorname{Ig} A \mathrm{gm} / \mathrm{l}$ \\
\hline 1 & $\mathrm{E}$ & 1.31 & 0.43 & 22.80 & 1.59 & 4.17 \\
\hline 2 & $\mathrm{E}$ & 1.92 & 0.44 & 15.00 & 0.57 & 1.06 \\
\hline 3 & $\mathrm{E}$ & 1.48 & 0.17 & 15.20 & 0.83 & 1.70 \\
\hline 4 & $\mathrm{E}$ & 1.83 & 0.28 & 17.90 & 1.23 & 0.56 \\
\hline 5 & $\mathrm{E}$ & 1.07 & 0.09 & 27.00 & 1.57 & 3.55 \\
\hline 6 & $\mathrm{E}$ & 1.19 & 0.13 & 21.80 & 1.38 & 3.84 \\
\hline 7 & $\mathrm{E}$ & 1.65 & 0.38 & 13.30 & 1.82 & 1.16 \\
\hline 8 & $\mathrm{E}$ & 1.80 & 0.20 & 23.30 & 1.49 & 0.92 \\
\hline 9 & E & 1.95 & 0.40 & 15.10 & 1.82 & 1.47 \\
\hline 10 & $\mathrm{E}$ & 1.46 & 0.46 & 14.60 & 1.72 & 3.53 \\
\hline 11 & $\mathrm{E}$ & 1.76 & 0.44 & 13.40 & 1.43 & 1.76 \\
\hline 12 & $\mathrm{E}$ & 1.37 & 0.15 & 28.40 & 1.43 & 1.38 \\
\hline 13 & $\mathrm{E}$ & 1.58 & 0.16 & 15.30 & 1.36 & 2.63 \\
\hline 14 & $\mathrm{E}$ & 1.42 & 0.13 & 15.40 & 1.32 & 1.09 \\
\hline 15 & $\mathrm{E}$ & 1.31 & 0.18 & 17.20 & 1.23 & 1.38 \\
\hline 16 & $\mathrm{E}$ & 1.48 & 0.26 & 15.30 & 1.39 & 2.74 \\
\hline 17 & $\mathrm{~N}$ & 1.72 & 0.45 & 17.70 & 1.17 & 1.96 \\
\hline 18 & $\mathrm{~N}$ & 1.58 & 0.34 & 16.10 & 1.33 & 2.51 \\
\hline 19 & $\mathrm{~N}$ & 1.31 & 0.23 & 14.60 & 0.69 & 2.88 \\
\hline 20 & $\mathrm{~N}$ & 1.64 & 0.33 & 17.50 & 5.47 & 3.72 \\
\hline 21 & $\mathrm{~N}$ & 1.75 & 0.16 & 22.00 & 3.42 & 3.29 \\
\hline 22 & $\mathrm{~N}$ & 1.63 & 0.21 & 17.30 & 4.12 & 2.56 \\
\hline 23 & $\mathrm{~N}$ & 1.38 & 0.39 & 16.70 & 2.42 & 1.88 \\
\hline 24 & $\mathrm{~N}$ & 1.73 & 0.26 & 12.00 & 0.80 & 3.11 \\
\hline 25 & $\mathrm{~N}$ & 1.53 & 0.17 & 21.30 & 2.43 & 3.62 \\
\hline
\end{tabular}

Table. 2 Experimental findings along with earlier work carried out by researchers.

\begin{tabular}{cccccc}
\hline S.No. & Immuno-logical Parameter & Types of Samples & Mean \pm S.D Unit & Disease/Control & Reference \\
\hline 1 & $C_{3}$ & Serum & $(133.8 \pm 29.7) \mathrm{mg} / \mathrm{dl}$ & Control & $\begin{array}{c}\text { Al-Hakeim. H.K. } \\
\text { et al. }[40]\end{array}$ \\
2 & $C_{3}$ & Serum & $(171.3 \pm 81.2) \mathrm{mg} / \mathrm{dl}$ & Depressed & Do \\
3 & $C_{4}$ & Serum & $(26.8 \pm 7.9) \mathrm{mg} / \mathrm{dl}$ & Control & Do \\
4 & $C_{4}$ & Serum & $(5.6 \pm 21.7) \mathrm{mg} / \mathrm{dl}$ & Depressed & Do \\
5 & $I g A$ & Serum & $(218.9 \pm 127.6) \mathrm{mg} / \mathrm{dl}$ & Control & Do \\
6 & $I g A$ & Serum & $(253.3 \pm 188.7) \mathrm{mg} / \mathrm{dl}$ & Depressed & Do \\
7 & $I g G$ & Serum & $(1128.4 \pm 413.7) \mathrm{mg} / \mathrm{dl}$ & Control & Do \\
8 & $I g G$ & Serum & $(1652.4 \pm 849.5) \mathrm{mg} / \mathrm{dl}$ & Depressed & Do \\
\hline
\end{tabular}




\section{Continued}

\begin{tabular}{|c|c|c|c|c|c|}
\hline 9 & $\operatorname{IgM}$ & Serum & $(176.4 \pm 92.3) \mathrm{mg} / \mathrm{dl}$ & Control & Do \\
\hline 10 & $\operatorname{IgM}$ & Serum & $(158.5 \pm 83.4) \mathrm{mg} / \mathrm{dl}$ & Depressed & Do \\
\hline 11 & $C_{3}$ & Serum & $(0.80 \pm 0.10) \mathrm{mg} / \mathrm{dl}$ & Control & Olsson, R. et al. [57] \\
\hline 12 & $C_{3}$ & Serum & $(0.85 \pm 0.16) \mathrm{g} / 1$ & Epilepsy & Do \\
\hline 13 & $C_{4}$ & Serum & $(86 \pm 26) g / 1$ & Control & Do \\
\hline 14 & $C_{4}$ & Serum & $(85 \pm 33) \mathrm{g} / 1$ & Epilepsy & Do \\
\hline 15 & $I g G$ & Serum & $(11 \pm 2.5) \mathrm{g} / 1$ & Control & Do \\
\hline 16 & $\operatorname{Ig} G$ & Serum & $(9.5 \pm 1.1) \mathrm{g} / 1$ & Epilepsy & Do \\
\hline 17 & $\operatorname{IgA}$ & Serum & $(1.7 \pm 0.6) g / 1$ & Control & Do \\
\hline 18 & $\operatorname{IgA}$ & Serum & $(1.5 \pm 1.1) \mathrm{g} / 1$ & Epilepsy & Do \\
\hline 19 & $\operatorname{IgM}$ & Serum & $(1.5 \pm 0.4) \mathrm{g} / 1$ & Control & Do \\
\hline 20 & $\operatorname{IgM}$ & Serum & $(1.6 \pm 0.8) \mathrm{g} / 1$ & Epilepsy & Do \\
\hline 21 & $I g G$ & CSF & $(0.019 \pm 0.005) \mathrm{g} / 1$ & Control & Milica, T.C. et al. [17] \\
\hline 22 & $I g G$ & Serum & $(9.8 \pm 2.7) \mathrm{g} / 1$ & Control & Do \\
\hline 23 & $C_{3}$ & $\mathrm{CSF}$ & $(0.0020 \pm 0.004) \mathrm{g} / 1$ & Control & Do \\
\hline 24 & $C_{3}$ & Serum & $(1.13 \pm 0.21) \mathrm{g} / 1$ & Control & Do \\
\hline 25 & $C_{4}$ & $\mathrm{CSF}$ & $(0.0007 \pm 0.0002) \mathrm{g} / 1$ & Control & Do \\
\hline 26 & $C_{4}$ & Serum & $(0.25 \pm 0.08) \mathrm{g} / 1$ & Control & Do \\
\hline 27 & $I g G$ & $\mathrm{CSF}$ & $(0.386 \pm 0.658) \mathrm{g} / 1$ & $\begin{array}{l}\text { Hemorrhages into } \\
\text { CNS Accuta }\end{array}$ & Do \\
\hline 28 & $I g G$ & Serum & $(14.4 \pm 1.8) \mathrm{g} / 1$ & Do & Do \\
\hline 29 & $C_{3}$ & $\mathrm{CSF}$ & $(0.015 \pm 0.016) \mathrm{g} / 1$ & Do & Do \\
\hline 30 & $C_{3}$ & Serum & $(1.15 \pm 0.15) \mathrm{g} / 1$ & Do & Do \\
\hline 31 & $C_{4}$ & $\mathrm{CSF}$ & $(0.0049 \pm 0.0044) \mathrm{g} / 1$ & Do & Do \\
\hline 32 & $C_{4}$ & Serum & $(0.29 \pm 0.06) \mathrm{g} / 1$ & Do & Do \\
\hline 33 & $I g G$ & $\mathrm{CSF}$ & $(0.060 \pm 0.027) \mathrm{g} / 1$ & $\begin{array}{c}\text { Ischemic Cerebrovascular } \\
\text { Accident }\end{array}$ & Do \\
\hline 34 & $I g G$ & Serum & $(13.0 \pm 2.3) \mathrm{g} / 1$ & Do & Do \\
\hline 35 & $C_{3}$ & $\mathrm{CSF}$ & $(0.0045 \pm 0.0016) \mathrm{g} / 1$ & Do & Do \\
\hline 36 & $C_{3}$ & Serum & $(1.17 \pm 0.18) \mathrm{g} / 1$ & Do & Do \\
\hline 37 & $C_{4}$ & $\mathrm{CSF}$ & $(0.0021 \pm 0.009) \mathrm{g} / 1$ & Do & Do \\
\hline 38 & $C_{4}$ & Serum & $(0.30 \pm 0.08) \mathrm{g} / 1$ & Do & Do \\
\hline 39 & $C_{3}$ & $\mathrm{CSF}$ & $(0.0014 \pm 0.0003) \mathrm{g} / 1$ & Meningism & Do \\
\hline 40 & $C_{3}$ & Serum & $(1.14 \pm 0.14) \mathrm{g} / 1$ & Do & Do \\
\hline 41 & $C_{4}$ & $\mathrm{CSF}$ & $(0.004 \pm 0.003) \mathrm{g} / 1$ & Do & Do \\
\hline 42 & $C_{4}$ & Serum & $(0.22 \pm 0.06) \mathrm{g} / 1$ & Do & Do \\
\hline
\end{tabular}




\section{Continued}

\begin{tabular}{|c|c|c|c|c|c|}
\hline 43 & $I g G$ & $\mathrm{CSF}$ & $(0.012 \pm 0.005) \mathrm{g} / 1$ & Do & Do \\
\hline 44 & $I g G$ & Serum & $(12.8 \pm 1.9) \mathrm{g} / 1$ & Do & Do \\
\hline 45 & $C_{3}$ & $\mathrm{CSF}$ & $(0.0039 \pm 0.0015) \mathrm{g} / 1$ & $\begin{array}{l}\text { Meningitis } \\
\text { Serosa + Aspetic } \\
\text { Meningitis }\end{array}$ & Do \\
\hline 46 & $C_{3}$ & Serum & $(1.31 \pm 0.20) \mathrm{g} / 1$ & Do & Do \\
\hline 47 & $C_{4}$ & $\mathrm{CSF}$ & $(0.0012 \pm 0.0005) \mathrm{g} / 1$ & Do & Do \\
\hline 48 & $C_{4}$ & Serum & $(0.32 \pm 0.0008) \mathrm{g} / 1$ & Do & Do \\
\hline 49 & $I g G$ & $\mathrm{CSF}$ & $(0.034 \pm 0.018) \mathrm{g} / 1$ & Do & Do \\
\hline 50 & $\operatorname{IgG}$ & Serum & $(13.2 \pm 3.4) \mathrm{g} / 1$ & Do & Do \\
\hline 51 & $C_{3}$ & CSF & $(0.0048 \pm 0.0020) \mathrm{g} / 1$ & Ig Synthesis Proven & Do \\
\hline 52 & $C_{3}$ & Serum & $(1.35 \pm 0.32) \mathrm{g} / 1$ & Do & Do \\
\hline 53 & $C_{4}$ & $\mathrm{CSF}$ & $(0.0020 \pm 0.0008) \mathrm{g} / 1$ & Do & Do \\
\hline 54 & $C_{4}$ & Serum & $(0.31 \pm 0.09) \mathrm{g} / 1$ & Do & Do \\
\hline 55 & $\operatorname{Ig} G$ & $\mathrm{CSF}$ & $(0.048 \pm 0.031) \mathrm{g} / 1$ & Do & Do \\
\hline 56 & $\operatorname{IgG}$ & Serum & $(12.2 \pm 2.9) \mathrm{g} / 1$ & Do & Do \\
\hline 57 & $\mathrm{C}_{3}$ & $\mathrm{CSF}$ & $(0.0054 \pm 0.0030) \mathrm{g} / 1$ & $\begin{array}{c}\text { Encephalitis }+ \text { Meningo } \\
\text { Encephalitis }\end{array}$ & Do \\
\hline 58 & $\mathrm{C}_{3}$ & Serum & $(1.07 \pm 0.30) \mathrm{g} / 1$ & Do & Do \\
\hline 59 & $\mathrm{C}_{4}$ & CSF & $(0.0019 \pm 0.0010) \mathrm{g} / 1$ & Do & Do \\
\hline 60 & $\mathrm{C}_{4}$ & Serum & $(0.22 \pm 0.07) \mathrm{g} / 1$ & Do & Do \\
\hline 61 & $\operatorname{IgG}$ & $\mathrm{CSF}$ & $(0.049 \pm 0.025) \mathrm{g} / 1$ & Do & Do \\
\hline 62 & $I g G$ & Serum & $(11.2 \pm 3.2) \mathrm{g} / 1$ & Do & Do \\
\hline 63 & $C_{3}$ & $\mathrm{CSF}$ & $(0.0120 \pm 0.0064) \mathrm{g} / 1$ & $\begin{array}{l}\text { Guillain-Barre Syndrone } \\
\text { Acute }\end{array}$ & Do \\
\hline 64 & $C_{3}$ & Serum & $(1.25 \pm 0.27) \mathrm{g} / 1$ & Do & Do \\
\hline 65 & $C_{4}$ & $\mathrm{CSF}$ & $(0.0022 \pm 0.0013) \mathrm{g} / 1$ & Do & Do \\
\hline 66 & $C_{4}$ & Serum & $(0.26 \pm 0.07) \mathrm{g} / 1$ & Do & Do \\
\hline 67 & $I g G$ & $\mathrm{CSF}$ & $(0.141 \pm 0.082) \mathrm{g} / 1$ & Do & Do \\
\hline 68 & $I g G$ & Serum & $(11.0 \pm 2.8) \mathrm{g} / 1$ & Do & Do \\
\hline 69 & $C_{3}$ & $\mathrm{CSF}$ & $(0.0080 \pm 0.0046) \mathrm{g} / 1$ & $\begin{array}{l}\text { Guillain-Barre Syndrome } \\
\text { Chronic Course }\end{array}$ & Do \\
\hline 70 & $C_{3}$ & Serum & $(1.10 \pm 0.20) \mathrm{g} / 1$ & Do & Do \\
\hline 71 & $C_{4}$ & $\mathrm{CSF}$ & $(0.0022 \pm 0.0013) \mathrm{g} / 1$ & Do & Do \\
\hline 72 & $C_{4}$ & Serum & $(0.26 \pm 0.07) \mathrm{g} / 1$ & Do & Do \\
\hline 73 & $I g G$ & $\mathrm{CSF}$ & $(0.100 \pm 0.64) \mathrm{g} / 1$ & Do & Do \\
\hline 74 & $\operatorname{IgG}$ & Serum & $(12.8 \pm 3.0) \mathrm{g} / 1$ & Do & Do \\
\hline 75 & $C_{3}$ & $\mathrm{CSF}$ & $(0.0027 \pm 0.0009) \mathrm{g} / 1$ & $\begin{array}{c}\text { Multiple Sclerosis Normal } \\
\text { Complement }\end{array}$ & Do \\
\hline
\end{tabular}




\section{Continued}

\begin{tabular}{|c|c|c|c|c|c|}
\hline 76 & $C_{3}$ & Serum & $(1.00 \pm 0.23) \mathrm{g} / 1$ & Do & Do \\
\hline 77 & $C_{4}$ & CSF & $(6.0012 \pm 0.0005) \mathrm{g} / 1$ & Do & Do \\
\hline 78 & $C_{4}$ & Serum & $(0.23 \pm 0.07) \mathrm{g} / 1$ & Do & Do \\
\hline 79 & $\operatorname{IgG}$ & CSF & $(0.070 \pm 0.030) \mathrm{g} / 1$ & Do & Do \\
\hline 80 & $\operatorname{IgG}$ & Serum & $(10.6 \pm 1.5) \mathrm{g} / 1$ & Do & Do \\
\hline 81 & $C_{3}$ & CSF & $(0.0033 \pm 0.0009) \mathrm{g} / 1$ & Complement Activation & Do \\
\hline 82 & $C_{3}$ & Serum & $(0.93 \pm 0.20) \mathrm{g} / 1$ & Do & Do \\
\hline 83 & $C_{4}$ & CSF & $(0.0017 \pm 0.0004) \mathrm{g} / 1$ & Do & Do \\
\hline 84 & $C_{4}$ & Serum & $(0.21 \pm 0.05) \mathrm{g} / 1$ & Do & Do \\
\hline 85 & $\operatorname{IgG}$ & CSF & $(0.064 \pm 0.033) \mathrm{g} / 1$ & Do & Do \\
\hline 86 & $\operatorname{IgG}$ & Serum & $(11.1 \pm 2.0) \mathrm{g} / 1$ & Do & Do \\
\hline 87 & $C_{3}$ & CSF & $(0.0032 \pm 0.0014) \mathrm{g} / 1$ & $\begin{array}{l}\text { Suspected MS with } \\
\text { Progressive Course }\end{array}$ & \\
\hline 88 & $C_{3}$ & Serum & $(0.89 \pm 0.21) \mathrm{g} / 1$ & Do & Do \\
\hline 89 & $C_{4}$ & CSF & $(0.0013 \pm 0.0005) \mathrm{g} / 1$ & Do & Do \\
\hline 90 & $C_{4}$ & Serum & $(0.18 \pm 0.07) \mathrm{g} / 1$ & Do & Do \\
\hline 91 & $\operatorname{Ig} G$ & CSF & $(0.032 \pm 0.015) \mathrm{g} / 1$ & Do & Do \\
\hline 92 & $\operatorname{IgG}$ & Serum & $(11.7 \pm 2.3) \mathrm{g} / 1$ & Do & Do \\
\hline 93 & $C_{3}$ & CSF & $(0.0039 \pm 0.0027) \mathrm{g} / 1$ & $\begin{array}{c}\text { Radiculopathies } \\
\text { Compressive Accuta }\end{array}$ & Do \\
\hline 94 & $C_{3}$ & Serum & $(1.08 \pm 0.20) \mathrm{g} / 1$ & Do & Do \\
\hline 95 & $C_{4}$ & $\mathrm{CSF}$ & $(0.0016 \pm 0.0005) \mathrm{g} / 1$ & Do & Do \\
\hline 96 & $C_{4}$ & Serum & $(0.23 \pm 0.05) \mathrm{g} / 1$ & Do & Do \\
\hline 97 & $I g G$ & $\mathrm{CSF}$ & $(0.049 \pm 0.031) \mathrm{g} / 1$ & Do & Do \\
\hline 98 & $\operatorname{IgG}$ & Serum & $(12.0 \pm 2.2) \mathrm{g} / 1$ & Do & Do \\
\hline 99 & $C_{3}$ & $\mathrm{CSF}$ & $(0.0045 \pm 0.0018) \mathrm{g} / 1$ & Complecated Sequele & Do \\
\hline 100 & $C_{3}$ & Serum & $(1.06 \pm 0.25) \mathrm{g} / 1$ & Do & Do \\
\hline 101 & $C_{4}$ & $\mathrm{CSF}$ & $(0.0020 \pm 0.0006) \mathrm{g} / 1$ & Do & Do \\
\hline 102 & $C_{4}$ & Serum & $(0.22 \pm 0.06) \mathrm{g} / 1$ & Do & Do \\
\hline 103 & $\operatorname{Ig} G$ & $\mathrm{CSF}$ & $(0.044 \pm 0.016) \mathrm{g} / 1$ & Do & Do \\
\hline 104 & $I g G$ & Serum & $(11.6 \pm 2.0) \mathrm{g} / 1$ & Do & Do \\
\hline 105 & $C_{3}$ & CSF & $(0.0041 \pm 0.0015) \mathrm{g} / 1$ & $\begin{array}{l}\text { Spinal Cord Neoplastic } \\
\text { Processes }\end{array}$ & Do \\
\hline 106 & $C_{3}$ & Serum & $(1.05 \pm 0.18) \mathrm{g} / 1$ & Do & Do \\
\hline 107 & $C_{4}$ & $\mathrm{CSF}$ & $(0.0015 \pm 0.0005) \mathrm{g} / 1$ & Do & Do \\
\hline 108 & $C_{4}$ & Serum & $(0.19 \pm 0.05) \mathrm{g} / 1$ & Do & Do \\
\hline 109 & $\operatorname{IgG}$ & $\mathrm{CSF}$ & $(0.037 \pm 0.014) \mathrm{g} / 1$ & Do & Do \\
\hline
\end{tabular}




\section{Continued}

\begin{tabular}{|c|c|c|c|c|c|}
\hline 110 & $I g G$ & Serum & $(12.6 \pm 3.0) \mathrm{g} / 1$ & Do & Do \\
\hline 111 & $C_{3}$ & CSF & $(0.0033 \pm 0.0015) \mathrm{g} / 1$ & Motor Neuron Disease & Do \\
\hline 112 & $C_{3}$ & Serum & $(1.26 \pm 0.20) \mathrm{g} / 1$ & Do & Do \\
\hline 113 & $C_{4}$ & $\mathrm{CSF}$ & $(0.0015 \pm 0.0005) \mathrm{g} / 1$ & Do & Do \\
\hline 114 & $C_{4}$ & Serum & $(0.26 \pm 0.10) \mathrm{g} / 1$ & Do & Do \\
\hline 115 & $I g G$ & $\mathrm{CSF}$ & $(0.030 \pm 0.017) \mathrm{g} / 1$ & Do & Do \\
\hline 116 & $\operatorname{Ig} G$ & Serum & $(11.4 \pm 2.6) \mathrm{g} / 1$ & Do & Do \\
\hline 117 & $C_{3}$ & CSF & $(0.0780 \pm 0.1155) \mathrm{g} / 1$ & CNS Tumors & Do \\
\hline 118 & $C_{3}$ & Serum & $(1.08 \pm 0.22) \mathrm{g} / 1$ & Do & Do \\
\hline 119 & $C_{4}$ & CSF & $(0.0220 \pm 0.0286) \mathrm{g} / 1$ & Do & Do \\
\hline 120 & $C_{4}$ & Serum & $(0.25 \pm 0.07) \mathrm{g} / 1$ & Do & Do \\
\hline 121 & $\operatorname{Ig} G$ & $\mathrm{CSF}$ & $(0.970 \pm 1.110) \mathrm{g} / 1$ & Do & Do \\
\hline 122 & $\operatorname{Ig} G$ & Serum & $(11.5 \pm 4.3) \mathrm{g} / 1$ & Do & Do \\
\hline 123 & $I g G$ & CSF & $(7.4 \pm 0) \mathrm{g} / 100$ & Epilepsy & Riddoch, D. et al.,[42] \\
\hline 124 & $I g G$ & CSF & $(9.0 \pm 0) \mathrm{ml} / 100$ & Motor Neurone Disease & Do \\
\hline 125 & $\operatorname{IgA}$ & Serum & $(2.26 \pm 1.15) \mathrm{IU} / \mathrm{ml}$ & Control & Gholamali, Y.P. et al. [20] \\
\hline 126 & $\operatorname{Ig} A$ & Serum & $(2.23 \pm 1.05) \mathrm{IU} / \mathrm{ml}$ & Tonic-Clonic Epilepsy & Do \\
\hline 127 & $I g G$ & Serum & $(12.87 \pm 6.3) \mathrm{IU} / \mathrm{ml}$ & Control & Do \\
\hline 128 & $\operatorname{Ig} G$ & Serum & $(12.77 \pm 6.4) \mathrm{IU} / \mathrm{ml}$ & Tonic-Clonic Epilepsy & Do \\
\hline 129 & $\operatorname{Ig} M$ & Serum & $(2.13 \pm 1.72) \mathrm{IU} / \mathrm{ml}$ & Control & Do \\
\hline 130 & $\operatorname{Ig} M$ & Serum & $(2.23 \pm 1.82) \mathrm{IU} / \mathrm{ml}$ & Tonic-Clonic Epilepsy & Do \\
\hline 131 & $\operatorname{Ig} A$ & Serum & $(248 \pm 2) \mathrm{mg} / 100 \mathrm{ml}$ & $\mathrm{C}$ & Slavin, et al., [28] \\
\hline 132 & $\operatorname{Ig} A$ & Serum & $(196 \pm 2) \mathrm{mg} / 100 \mathrm{ml}$ & E & Do \\
\hline 133 & $I g G$ & Serum & $(950 \pm 2) \mathrm{mg} / 100 \mathrm{ml}$ & $\mathrm{C}$ & Do \\
\hline 134 & $\operatorname{IgG}$ & Serum & $(1206 \pm 2) \mathrm{mg} / 100 \mathrm{ml}$ & E & Do \\
\hline 135 & $\operatorname{IgM}$ & Serum & $(94 \pm 2) \mathrm{mg} / 100 \mathrm{ml}$ & $\mathrm{C}$ & Do \\
\hline 136 & $\operatorname{IgM}$ & Serum & $(142 \pm 2) \mathrm{mg} / 100 \mathrm{ml}$ & E & Do \\
\hline 137 & $\operatorname{IgM}$ & Serum & $(153 \pm 11.5) \mathrm{mg} / 100 \mathrm{ml}$ & $\mathrm{C}$ & Do \\
\hline 138 & $\operatorname{IgM}$ & Serum & $(64.1 \pm 5.4) \mathrm{mg} / 100 \mathrm{ml}$ & E. (Grade I) & Moustafa, S. et al.[58] \\
\hline 139 & $\operatorname{IgM}$ & Serum & $(55.1 \pm 5.9) \mathrm{mg} / 100 \mathrm{ml}$ & E. (Grade II) & Do \\
\hline 140 & $\operatorname{IgM}$ & Serum & $(35.1 \pm 5.8) \mathrm{mg} / 100 \mathrm{ml}$ & E. (Grade III) & Do \\
\hline 141 & $\operatorname{Ig} G$ & Serum & $(945 \pm 107) \mathrm{mg} / 100 \mathrm{ml}$ & $\mathrm{C}$ & Do \\
\hline 142 & $I g G$ & Serum & $(795.6 \pm 90) \mathrm{mg} / 100 \mathrm{ml}$ & E. (Grade I) & Do \\
\hline 143 & $I g G$ & Serum & $(745 \pm 35.1) \mathrm{mg} / 100 \mathrm{ml}$ & E. (Grade II) & Do \\
\hline
\end{tabular}




\section{Continued}

\begin{tabular}{|c|c|c|c|c|c|}
\hline 144 & $\operatorname{IgG}$ & Serum & $(403.4 \pm 10.5) \mathrm{mg} / 100 \mathrm{ml}$ & E. (Grade III) & Do \\
\hline 145 & $\operatorname{IgA}$ & Serum & $(154 \pm 69) \mathrm{mg} / \mathrm{dl}$ & $\mathrm{C}$ & Kumar, S. [59] Thesis \\
\hline 146 & $\operatorname{Ig} A$ & Serum & $(320 \pm 21) \mathrm{mg} / \mathrm{dl}$ & GME & Do \\
\hline 147 & $\operatorname{IgG}$ & Serum & $(1169 \pm 351) \mathrm{mg} / \mathrm{dl}$ & $\mathrm{C}$ & Do \\
\hline 148 & $\operatorname{IgG}$ & Serum & $(2774 \pm 161) \mathrm{mg} / \mathrm{dl}$ & GME & Do \\
\hline 149 & $\operatorname{Ig} M$ & Serum & $(188 \pm 62) \mathrm{mg} / \mathrm{dl}$ & $\mathrm{C}$ & Do \\
\hline 150 & $\operatorname{Ig} M$ & Serum & $(280 \pm 24) \mathrm{mg} / \mathrm{dl}$ & GME & Do \\
\hline 151 & $C_{3}$ & Serum & $(93 \pm 7) \mathrm{mg} / \mathrm{dl}$ & GME & Do \\
\hline 152 & $C_{3}$ & Serum & $(108 \pm 24) \mathrm{mg} / \mathrm{dl}$ & $\mathrm{C}$ & Do \\
\hline 153 & $C_{4}$ & Serum & $(30 \pm 4) \mathrm{mg} / \mathrm{dl}$ & $\mathrm{C}$ & Do \\
\hline 154 & $C_{4}$ & Serum & $(37 \pm 4) \mathrm{mg} / \mathrm{dl}$ & GME & Do \\
\hline 155 & $\operatorname{Ig} A$ & Serum & $(161 \pm 10) \mathrm{mg} / \mathrm{dl}$ & E & $\begin{array}{c}\text { Anderson, P. \& Moseklide, } \\
\text { L. [34] }\end{array}$ \\
\hline 156 & $\operatorname{IgG}$ & Serum & $(1217 \pm 359) \mathrm{mg} / \mathrm{dl}$ & $\mathrm{E}$ & Do \\
\hline 157 & $\operatorname{Ig} M$ & Serum & $(157 \pm 72) \mathrm{mg} / \mathrm{dl}$ & $\mathrm{E}$ & Do \\
\hline 158 & $\operatorname{Ig} A$ & Serum & $(142 \pm 66) \mathrm{mg} / \mathrm{dl}$ & Migraine & Moore et al., [60] \\
\hline 159 & $\operatorname{IgG}$ & Serum & $(1344 \pm 448) \mathrm{mg} / \mathrm{dl}$ & Do & Do \\
\hline 160 & $\operatorname{Ig} M$ & Serum & $(141 \pm 80) \mathrm{mg} / \mathrm{dl}$ & Do & Do \\
\hline 161 & $\operatorname{Ig} A$ & Serum & $(143 \pm 66) \mathrm{mg} / \mathrm{dl}$ & Headache free & Do \\
\hline 162 & $\operatorname{IgG}$ & Serum & $(1394 \pm 530) \mathrm{mg} / \mathrm{dl}$ & Do & Do \\
\hline 163 & $\operatorname{Ig} M$ & Serum & $(144 \pm 75) \mathrm{mg} / \mathrm{dl}$ & Do & Do \\
\hline 164 & $\operatorname{Ig} A$ & Serum & $(160 \pm 63) \mathrm{mg} / \mathrm{dl}$ & Prodromal Migraine & Do \\
\hline 165 & $\operatorname{IgG}$ & Serum & $(1456 \pm 400) \mathrm{mg} / \mathrm{dl}$ & Do & Do \\
\hline 166 & $\operatorname{Ig} M$ & Serum & $(133 \pm 80) \mathrm{mg} / \mathrm{dl}$ & Do & Do \\
\hline 167 & $\operatorname{IgA}$ & Serum & $(133 \pm 70) \mathrm{mg} / \mathrm{dl}$ & $\begin{array}{l}\text { Non-Prodromal } \\
\text { (Migrance) }\end{array}$ & Do \\
\hline 168 & $\operatorname{IgG}$ & Serum & $(1250 \pm 433) \mathrm{mg} / \mathrm{dl}$ & Do & Do \\
\hline 169 & $\operatorname{Ig} M$ & Serum & $(144 \pm 74) \mathrm{mg} / \mathrm{dl}$ & Do & Do \\
\hline 170 & $\operatorname{Ig} A$ & Serum & $(144 \pm 66) \mathrm{mg} / \mathrm{dl}$ & Prodroml (Headachetree) & Do \\
\hline 171 & $\operatorname{IgG}$ & Serum & $(1518 \pm 530) \mathrm{mg} / \mathrm{dl}$ & Do & Do \\
\hline 172 & $\operatorname{Ig} M$ & Serum & $(150 \pm 64) \mathrm{mg} / \mathrm{dl}$ & Do & Do \\
\hline 173 & $\operatorname{IgA}$ & Serum & $(142 \pm 69) \mathrm{mg} / \mathrm{dl}$ & $\begin{array}{l}\text { Non-Prodromal } \\
\text { (Head Ache Free) }\end{array}$ & Do \\
\hline 174 & $\operatorname{IgG}$ & Serum & $(1258 \pm 473) \mathrm{mg} / \mathrm{dl}$ & Do & Do \\
\hline 175 & $\operatorname{IgM}$ & Serum & $(131 \pm 69) \mathrm{mg} / \mathrm{dl}$ & Do & Do \\
\hline 176 & $\operatorname{IgA}$ & Serum & $(212 \pm 18) \mathrm{mg} / \mathrm{dl}$ & Migraneous System & Lord and Duckworth [61] \\
\hline 177 & $\operatorname{IgG}$ & Serum & $(1293 \pm 54) \mathrm{mg} / \mathrm{dl}$ & Do & Do \\
\hline
\end{tabular}




\section{Continued}

\begin{tabular}{|c|c|c|c|c|c|}
\hline 178 & $\operatorname{Ig} M$ & Serum & $(161 \pm 11) \mathrm{mg} / \mathrm{dl}$ & Do & Do \\
\hline 179 & $C_{3}$ & Serum & $(106 \pm 9) \mathrm{mg} / \mathrm{dl}$ & Late Hecdacae & Do \\
\hline 180 & $C_{4}$ & Serum & $(101 \pm 11) \mathrm{mg} / \mathrm{dl}$ & Do & Do \\
\hline 181 & $C_{3}$ & Serum & $(81 \pm 5) \mathrm{mg} / \mathrm{dl}$ & Earlyheadache & Do \\
\hline 182 & $C_{4}$ & Serum & $(71 \pm 5) \mathrm{mg} / \mathrm{dl}$ & Do & Do \\
\hline 183 & $C_{3}$ & Serum & $(20 \pm 9) \mathrm{mg} / \mathrm{dl}$ & Migraine & Do \\
\hline 184 & $C_{4}$ & Serum & $(16 \pm 6) \mathrm{mg} / \mathrm{dl}$ & Do & Do \\
\hline 185 & $C_{3}$ & Do & $(142 \pm 38) \mathrm{mg} / \mathrm{dl}$ & Prodromal Headache Free & Moore, et al., [60] \\
\hline 186 & $C_{4}$ & Do & $(28 \pm 10) \mathrm{mg} / \mathrm{dl}$ & Do & Do \\
\hline 187 & $\mathrm{C}_{3}$ & Do & $(167 \pm 10) \mathrm{mg} / \mathrm{dl}$ & Non-Prodromal (Migraine) & Do \\
\hline 188 & $C_{4}$ & Do & $(27 \pm 7) \mathrm{mg} / \mathrm{dl}$ & Do & Do \\
\hline 189 & $C_{3}$ & Do & $(176 \pm 64) \mathrm{mg} / \mathrm{dl}$ & $\begin{array}{l}\text { Non Prodromal } \\
\text { (Headache Free) }\end{array}$ & Do \\
\hline 190 & $\mathrm{C}_{4}$ & Do & $(27 \pm 8) \mathrm{mg} / \mathrm{dl}$ & Do & Do \\
\hline 191 & $C_{3}$ & Do & $(172 \pm 65) \mathrm{mg} / \mathrm{dl}$ & Prodromal (Migraine) & Do \\
\hline 192 & $C_{4}$ & Do & $(24 \pm 6) \mathrm{mg} / \mathrm{dl}$ & Do & Do \\
\hline 193 & $C_{3}$ & Do & $(165 \pm 56) \mathrm{mg} / \mathrm{dl}$ & Controls & Do \\
\hline 194 & $C_{4}$ & Do & $(28 \pm 8) \mathrm{mg} / \mathrm{dl}$ & $\mathrm{C}$ & Do \\
\hline 195 & $I g G$ & Serum & $(18.18 \pm 4.71) \mathrm{mg} / 1$ & $\mathrm{E}$ & Present work \\
\hline 196 & $I g G$ & Serum & $(17.24 \pm 2.89) \mathrm{mg} / 1$ & $\mathrm{C}$ & Present work \\
\hline 197 & $\operatorname{Ig} M$ & Serum & $(1.38 \pm 0.31) \mathrm{mg} / \mathrm{l}$ & E & Present work \\
\hline 198 & $\operatorname{Ig} M$ & Serum & $(2.42 \pm 1.54) \mathrm{mg} / 1$ & $\mathrm{C}$ & Present work \\
\hline 199 & $\operatorname{IgA}$ & Serum & $(2.05 \pm 1.13) \mathrm{mg} / 1$ & E & Present work \\
\hline 200 & $\operatorname{Ig} A$ & Serum & $(2.83 \pm 0.62) \mathrm{mg} / 1$ & $\mathrm{C}$ & Present work \\
\hline 201 & $C_{3}$ & Serum & $(1.53 \pm 0.25) \mathrm{mg} / 1$ & $\mathrm{E}$ & Present work \\
\hline 202 & $C_{3}$ & Serum & $(1.58 \pm 0.14) \mathrm{mg} / \mathrm{l}$ & $\mathrm{C}$ & Present work \\
\hline 203 & $C_{4}$ & Serum & $(0.26 \pm 0.13) \mathrm{mg} / 1$ & $\mathrm{E}$ & Present work \\
\hline 204 & $C_{4}$ & Serum & $(0.28 \pm 0.09) \mathrm{mg} / 1$ & $\mathrm{C}$ & Present work \\
\hline
\end{tabular}

most infectious agents, the same barrier may stop viral clearance. Immune responses in the CNS during infection are recruited from the systemic circulation in a relatively selective and specific fashion. Cells and antibodies found in the CNS during infections differ from these that follow non specific rupture in the BBB such as it occurs after a traumatic injury of any type injury may be one of the causes of epileptic attack. In traumatic lesion the transudate of serum contains antibodies and cells of all types enter, but with a predominance of monocytes, which dif- ferentiate into macrophases. During the stage of viral infection, we have an early increase in permeability of vessels, which allow transudation of serum proteins, cell entry is immunologically specific. The cells, which are entering have a specific kinetics and do not simply mirror the proportions of cell phenotypes in the blood. These cells in turn are caused to replicate cells, which may persist for long periods of time within CNS. On the basis of the above mentioned facts a review immune response in the CNS is quit necessary and required. Some of the re- 
Table 3. Mean levels and standard deviation of $C_{3}, C_{4}, \operatorname{IgG}, \operatorname{Ig} M, \operatorname{IgA}$ in epileptic patient and normal healthy control.

\begin{tabular}{|c|c|c|c|}
\hline S.No & Type of samples & Experimental findings Mean \pm SD & Diagnosis \\
\hline \multirow[b]{2}{*}{1.} & & $(1.5362 \pm 0.2623) \mathrm{g} / 1$ & Epilepsy \\
\hline & $C_{3}$ & $(1.5855 \pm 0.1550) \mathrm{g} / 1$ & Control \\
\hline \multirow{2}{*}{2} & & $(0.2687 \pm 0.1341) \mathrm{g} / 1$ & Epilepsy \\
\hline & $C_{4}$ & $(1.2822 \pm 0.1008) \mathrm{g} / 1$ & Control \\
\hline \multirow[b]{2}{*}{3} & & $(18.1875 \pm 4.8731) \mathrm{g} / 1$ & Epilepsy \\
\hline & $\operatorname{IgG}$ & $(17.2444 \pm 3.0708) \mathrm{g} / 1$ & Control \\
\hline \multirow[b]{2}{*}{4} & & $(1.3862 \pm 0.3273) \mathrm{g} / 1$ & Epilepsy \\
\hline & $\operatorname{IgM}$ & $(2.4277 \pm 1.6416) \mathrm{g} / 1$ & Control \\
\hline \multirow[b]{2}{*}{5} & & $(2.0587 \pm 1.1713) \mathrm{g} / 1$ & Epilepsy \\
\hline & $\operatorname{Ig} A$ & $(2.8366 \pm 0.6854) \mathrm{g} / 1$ & Control \\
\hline
\end{tabular}

Table 4. Regression and correlation coefficient studies on $C_{3}, C_{4}, \operatorname{Ig} G, \operatorname{Ig} M$ and $\operatorname{IgA}$ in normal blood samples.

\begin{tabular}{|c|c|c|c|c|c|}
\hline S.No & Correlation Co. & Regression Co. & Regression Equation & $\begin{array}{c}\text { Partial } \\
\text { Correlation Coff. }\end{array}$ & Multiple Co. \\
\hline$C_{3}$ & $C_{3} C_{4}=-0.0256$ & $\begin{array}{l}b_{c_{3} C_{4}}=-0.0394 \\
b_{c_{3} C_{4}}=-0.0167\end{array}$ & $C_{3}=-0.0394 C_{4}+1.5966$ & - & \\
\hline$C_{4}$ & $C_{4} C_{3}=-0.0256$ & & $C_{4}=-0.0167 C_{3}+0.3087$ & - & \\
\hline $\operatorname{IgG}$ & $\operatorname{Ig} G \cdot \operatorname{Ig} M=0.4814$ & $\begin{array}{l}b_{G M}=0.9006 \\
b_{M G}=0.2574\end{array}$ & $\begin{array}{l}I g G=0.9006 \operatorname{Ig} M+15.0577 \\
I g M=0.2574 \operatorname{Ig} G-2.0109\end{array}$ & $r_{G M \cdot A}=0.4201$ & $R_{G M A}=0.2386$ \\
\hline $\operatorname{Ig} M$ & $\operatorname{Ig} M \cdot \operatorname{Ig} A=0.4140$ & $\begin{array}{l}b_{M A}=1.0214 \\
b_{A M}=0.1678\end{array}$ & $\begin{array}{l}\operatorname{Ig} A=0.1678 \operatorname{Ig} M+2.4291 \\
\operatorname{Ig} M=1.0214 \operatorname{Ig} A-0.4698\end{array}$ & $r_{A G M}=0.0943$ & $R_{A \cdot G M}=0.1788$ \\
\hline $\operatorname{IgA}$ & $\operatorname{IgG} \cdot \operatorname{IgA}=0.2746$ & $\begin{array}{l}b_{G A}=1.2673 \\
b_{A G}=0.0595\end{array}$ & $\begin{array}{l}\operatorname{Ig} G=1.2673 \operatorname{Ig} A+13.6493 \\
\operatorname{Ig} A=0.0595 \operatorname{Ig} G+1.8102\end{array}$ & $r_{M A \cdot G}=0.3344$ & $R_{M \cdot A G}=0.3177$ \\
\hline
\end{tabular}

Table 5. Regression and correlation coefficient studies on $C_{3}, C_{4}, \operatorname{Ig} G, \operatorname{Ig} M$ and $\operatorname{IgA}$ in epileptic blood samples.

\begin{tabular}{|c|c|c|c|c|c|}
\hline S.No & Correlation Co. & Regression Co. & Regression Equation & $\begin{array}{c}\text { Coefficient of } \\
\text { Partial co-relation }\end{array}$ & Multiple Co. \\
\hline$C_{3}$ & $C_{3} C_{4}=0.5566$ & $b_{C_{3} \cdot C_{4}}=1.0887$ & $C_{3}=1.0887 C_{4}+1.2436$ & - & \\
\hline$C_{4}$ & $C_{4} C_{3}=0.5566$ & $b_{C_{4} \cdot C_{3}}=0.2845$ & $C_{4}=0.2845 C_{3}-0.1684$ & - & \\
\hline $\operatorname{IgG}$ & $\operatorname{IgG} \cdot \operatorname{Ig} M=0.1404$ & $\begin{array}{l}b_{G \cdot M}=2.0907 \\
b_{M \cdot G}=0.0094\end{array}$ & $\begin{array}{l}I g G=2.0907 \operatorname{Ig} M+15.2891 \\
I g M=0.0094 \operatorname{Ig} G+1.2146\end{array}$ & $r_{G M \cdot A}=0.0609$ & $R_{G \cdot M A}=0.0778$ \\
\hline $\operatorname{Ig} M$ & $\operatorname{Ig} M \cdot \operatorname{Ig} A=0.3103$ & $\begin{array}{l}b_{M \cdot A}=0.0867 \\
b_{A \cdot M}=1.1104\end{array}$ & $\begin{array}{l}\operatorname{Ig} M=0.0867 \operatorname{Ig} A+1.2077 \\
\operatorname{Ig} A=1.1104 \operatorname{Ig} M+0.5193\end{array}$ & $r_{A G \cdot M}=0.2436$ & $R_{A \cdot G M}=0.1499$ \\
\hline $\operatorname{IgA}$ & $\operatorname{Ig} G \cdot \operatorname{Ig} A=0.2728$ & $\begin{array}{l}b_{G \cdot A}=1.1351 \\
b_{A \cdot G}=0.0655\end{array}$ & $\begin{array}{l}\operatorname{Ig} G=1.1351 \operatorname{Ig} A+15.8504 \\
I g A=0.0655 \operatorname{Ig} G+0.8658\end{array}$ & $r_{M A G G}=0.2855$ & $R_{M \cdot A G}=0.0996$ \\
\hline
\end{tabular}


Table 6. Student t test analysis, two tailed paired.

\begin{tabular}{|c|c|c|c|c|c|c|c|c|}
\hline S.No & Element & $t_{\text {test }}$ & $t_{\text {theo }}$ & $\mathrm{P}$ & df & Result & Null hypothesis & Conclusion \\
\hline 1 & $C_{3}$ & 0.5572 & 0.69 & 0.583 & 23 & $t_{\text {exp }}<t_{\text {theo }}$ & rejected & $\begin{array}{l}\text { Difference between the mean } C_{3} \\
\text { levels of epilepsy and that of } \\
\text { normal is strongly significant }\end{array}$ \\
\hline 2 & $C_{4}$ & 0.2617 & 0.69 & 0.796 & 23 & $t_{\exp }<t_{\text {theo }}$ & rejected & $\begin{array}{l}\text { Difference between the mean } C_{4} \\
\text { levels of epilepsy and that of } \\
\text { normal is strongly significant }\end{array}$ \\
\hline 3 & $\operatorname{Ig} G$ & 0.5224 & 0.69 & 0.606 & 23 & $t_{\text {exp }}<t_{\text {theo }}$ & rejected & $\begin{array}{l}\text { Difference between the mean } \\
I g G \text { levels of epilepsy and that } \\
\text { of normal is strongly significant }\end{array}$ \\
\hline 4 & $\operatorname{Ig} M$ & 2.4906 & 2.5 & 0.02 & 23 & $t_{\text {exp }}<t_{\text {theo }}$ & rejected & $\begin{array}{l}\text { Difference between the mean } \\
\text { IgM levels of epilepsy and that } \\
\text { of normal is strongly significant }\end{array}$ \\
\hline 5 & $\operatorname{Ig} A$ & 1.823 & 1.71 & 0.081 & 23 & $t_{\exp }>t_{\text {theo }}$ & accepted & Not significant \\
\hline
\end{tabular}

Table 7. Student t test analysis, two tailed paired.

\begin{tabular}{|c|c|c|c|c|c|c|c|c|}
\hline S.No & Element & $t_{\exp }$ & $t_{\text {theo }}$ & $\mathbf{P}$ & df & Result & $\begin{array}{c}\text { Null } \\
\text { hypothesis }\end{array}$ & Conclusion \\
\hline 1 & $C_{3}$ & 0.0588 & 0.71 & 0.955 & 8 & $t_{\text {exp }}<t_{\text {theo }}$ & rejected & $\begin{array}{l}\text { Difference between the mean } \\
C_{3} \text { levels of epilepsy and that } \\
\text { of normal is strongly } \\
\text { significant }\end{array}$ \\
\hline 2 & $C_{4}$ & 0.0649 & 0.71 & 0.95 & 8 & $t_{\text {exp }}<t_{\text {theo }}$ & rejected & $\begin{array}{l}\text { Difference between the mean } \\
C_{4} \text { levels of epilepsy and that } \\
\text { of normal is strongly } \\
\text { significant }\end{array}$ \\
\hline 3 & $\operatorname{IgG}$ & 1.0262 & 0.71 & 0.335 & 8 & $t_{\exp }>t_{\text {theo }}$ & accepted & Not significant \\
\hline 4 & $\operatorname{Ig} M$ & 1.9763 & 1.86 & 0.084 & 8 & $t_{\exp }>t_{\text {theo }}$ & accepted & Not significant \\
\hline 5 & $\operatorname{Ig} A$ & 1.355 & 0.71 & 0.212 & 8 & $t_{\exp }>t_{\text {theo }}$ & accepted & Not significant \\
\hline
\end{tabular}

searchers have proposed the hypothesis of immunological mechanism for the involvement of pathogenesis in epileptic attacks. Many of the patient of epilepsy have immune deficient state.

It has been seen that some of the epileptic patients develop auto immune disorders on antiepileptic drugs medication. Many of epileptic patients exhibit different autoantibodies without any clinically manifest autoimmune disorder. The immunological aspects of epilepsy are not confined to the depressive effect of some of the antiepileptic drugs (AEDs) upon the immune system. They also comprise factors relevant to the pathogenesis of some form of epilepsy as well as variety of clinical manifestations met in some patients with epilepsy. The immunologic reactions can be involved in the pathogenesis of some of the epileptic patients is not unexpected. Local immune reaction can give rise to focal cerebral lesions. Focal lesions may develop epileptic attack. It has been established this anti neuronal antibodies lead to epileptic attacks. Immune complexes are trapped in small vessels giving rise to attack of epilepsy. Anti phospholipids antibodies lead to small vascular lesion.
If the antiepileptic effect is due to a direct action upon the brain, the immunoglobulins have to cross the BBB. Many research studies indicate that the $\mathrm{BBB}$ has been broken down locally during generalised cerebral seizures. It has been established that the increased expression of proinflammatory molecule has been demonstrated in the brain of epileptic patients after surgery. Inflammatory reactions occur in epilepsy of different types and do not invoke an inflammatory pathophysiology such as temporal lobe epilepsy. Brain inflammation may be a common factor contributing of predisposing to the occurrence of seizures and cell death in different type of epilepsy. We would like to add here that a reversible induction of a selective $I g A$ deficiency might occur in some patients receiving antiepileptic drugs such as Phenytoin. Humoral immunity may alter in patients after the first attack of seizure.

It is believed that the changes in the levels of immunological paramenters in the present study and after the review of the literature are due to manifestation of the factors, which are responsible for this disease. Immunity is related with the food, which we eat. It has already been 
established that content of the food have some trace elements. The trace elements play a role in human immunity. If the level of these elements goes beyond the limit of normalcy even death may occur. On the other hand if the levels are lower side of the normal range something unnatural can happen. A relation between immunoglobulin, complement and trace element be consider in the future preview of the study.

Granata, T. et al. [62] have given their views on the pathogenic role of immunity in epilepsy. They have observed the efficacy of immune-modulating treatment. On the basis of clinical and experimental findings they also reported that innate and adaptive immunity may be involved in epilepsy. Epilepsy may be present as a symptom of different neurological perturbations. Aetiological explanation can not be identified directly. Some evidences show that autoimmune mechanisms might behave a role in epilepsy. The evidence for immunological mechanisms in epilepsy can be examined as, childhood epilepsy syndrome, epilepsy associated with other immunologicly mediatd disease and unselected groups of patients with epilepsy. Autoimmunity has also suspected to involve in the pathology of certain types of epilepsies. Antibodis can be epileptogenic. We are able to say that the level of $I g G$ in epileptic patients are measured as

$(18.1875 \pm 4.8737 \mathrm{mg} / \mathrm{l})$ and $(17.2444 \pm 3.0708) \mathrm{mg} / 1$ in normals respectively. The $I g G$ levels are higher in the present finding of epileptic patients, while $\operatorname{IgA}, \operatorname{IgM}, C_{3}$ $\& C_{4}$ levels are lower than normal values. On the basis of statistical analysis in multipole correlation a trend has been found in epileptic cases i.e.

$$
R_{A \cdot G M}>R_{M \cdot A G}>R_{G \cdot M A}
$$

A partial correlation coefficients analysis shows a trend, that is

$$
r_{M A \cdot G}>r_{A G \cdot M}>r_{G M \cdot A}
$$

In the present work an attempt is made to relate the circulatory level of $\operatorname{IgG}, \operatorname{IgA}$ and $\operatorname{Ig} M$ and complement $C_{3} \& C_{4}$ among the subjects undergoing an epileptic attack and comparing them with that of normal individuals.

\section{Conclusions}

It has been seen that the conventional antiepileptic treatment have many limitations in the treatment of epileptic cases. Although there has been great advance in the management of the epileptic patients by the application of newly invented developed antiepileptic drugs and surgical techniques. Some of the cases still remain in an interactable position. Immunoglobulin, steroids and ketogeinc diet may be tried and better results may be seen in the treating cases. Immunoglobulin treatment shows benefits in some autoimmune related epilepsy. This treatment has its own limitations in long term efficiency.
Steroids show significant improvement in many epileptic syndromes. Ketogenic diet has become one of the most reliable treatment for epileptic children. Ketoegenic diet is difficult to maintain because of low palatability. It shows a very high antiepileptic efficacy. These are some of the suggestive directions to neutralize the effect of the epileptic seizure and try to control. Humoral immunity is altered in children early after the first attack of epilepsy. This may be a consequence of an exogenous event, such as occurrence of infection and related to an interaction of the CNS. The alterations in the immunity of the epileptic patients may be done by the adjusting the level of these in the blood of epileptic patients after the supplementation of proper diet, which is rich in all necessary trace elements. The immunotoxic potential of anticonvulsant drugs appear to be very low. The immunological monitoring is required in all the patients. This monitoring is also required in those patients who are at stage of immune defect.

Our results show that the levels of $\operatorname{IgA}, \operatorname{IgM}, C_{3}$ and $C_{4}$ are lower than controls and the levels of $I g G$ are higher in all the epileptic cases. Statistical analysis shows a trend i.e.

$$
R_{A \cdot G M}>R_{M \cdot A G}>R_{G \cdot M A}
$$

The contributions of all these immunoglobulins are very strong i.e. $R_{M \cdot A G}$ has a value 0.0996 . If we have a higher value of $\operatorname{Ig} G$ the other values of $\operatorname{IgM}$ and $\operatorname{IgA}$ will be adjusted according to the application of multiple correlation coefficient analysis. We would like to add here that it is quite possible to have a genetic predisposition to develop $\operatorname{IgA}$ deficiency is completely unrelated to the genetic factors involved the pathogenesis of epilepsy. IgA deficiency may appear in many types if epilepsy and irrespective of a family background. Some of the studies showed that the deficiency of $\operatorname{Ig} A$ occurs in patients with generalized cerebral seizure and some time in partial epilepsies.

Aarli, J. A. [39] had reported some of the findings on allergy in epilepsy. A small percentage of patients treated with antiepileptic drugs develop transient exanthema. Exfoliative dermatitis or erythema multiforme exsudativum may develop in some cases. Various immunological parameters like $\operatorname{IgA}$. IgM, IgA, $C_{3}$ and $C_{4}$ complement were determined in almost one hundred cases and healthy controls were taken about twenty. Values of these parameters were very low in compression with healthy controls except IgG. The values of IgG levels are higher than controls.

Our results indicate that there is an altered immune mechanism in epileptic patients needs a modification in the treatment. It can be maintained by the proper supplementation by the ketogenic diet and trace element like $\mathrm{Na}, \mathrm{K} . \mathrm{Zn}, \mathrm{Fe}, \mathrm{Ca}, \mathrm{Mg}$ and $\mathrm{Cu}$. Green leafy vegetables 
may be given to the patients to control the seizure. Immunity is related with the food we eat. Researches have been made in the direction to increase the immunity with the proper diet. By adjusting the immunity with proper diet the severity of epileptic attack or any disease may be reduced.

\section{Acknowledgements}

The authors are thankful to Dr. P. K. Saxena, Principal, D.A.V. (P.G.) College, Muzaffarnagar for providing the facility of doing work. We are also thankful to Medical Supdt. of Safdarganj Hospital, New Delhi, for arranging the blood samples of the diseased and healthy controls. We are grateful to Dr. Manju Chauhan, Head, Department of Biosciences, D.A.V. (P.G.) College, Muzaffarnagar, for providing the facility of estimation of biological parameters.

\section{REFERENCES}

[1] P. Ehrlich, "Das Sauerstufbudurfnis des Organismus, in Eine Farbenanalytische Studie," Hirschwald, Berlin, 1885, p. 167.

[2] J. B. Murphy and E. Sturm, "Conditions Determining the Transplantability of Tissues in the Brain," The Journal of Experimental Medicine, Vol. 39, No. 2, 1923, pp. 183197. doi:10.1084/jem.38.2.183

[3] F. R. Sabin, "The Origin and Development of the Lymphatic System," Johns Hopkins Hospital Research, Vol. 17, No. 86, 1916, pp. 347-440.

[4] M. Ediden, "The Tissue Distribution and Cellular Location of Transplantation Antigens," In: B. D. Kanhan and R. A. Reisfeld, Eds., Transplantation Antigens, Academic Press Inc., New York, 1972, pp. 125-140.

[5] J. E. Blalock, "The Immune System as a Sensory Organ," The Journal of Immunology, Vol. 132, No. 3, 1984, pp. 1067-1070.

[6] S. Reichlin, "Neuroendocrine-Immune Interactions," The New England Journal of Medicine, Vol. 329, No. 17, 1993, pp. 1246-1253. doi:10.1056/NEJM199310213291708

[7] E. M. Sternberg, G. P. Chrousos, R. L. Wilder and P. W. Gold, "The Stress Response and the Regulation of Inflammatory Disease," Annals of Internal Medicine, Vol. 117, No. 10, 1992, pp. 854-866.

[8] D. A. Weigent and J. E. Blalock, "Interactions between the Neuroendocrine and Immune Systems: Common Hormones Receptors," Immunological Reviews, Vol. 100, 1987, pp. 79-108. doi:10.1111/j.1600-065X.1987.tb00528.x

[9] W. W. Tourtellotte, "On Cerebrospinal Fluid ImmunoglobulinG ( $\mathrm{IgG})$ Quotients in Multiple Sclerosis and Other Diseases. A Review and a New Formula to Estimate the Amount of IgG Synthesized Per Day by the Central Nervous System," Journal of the Neurological Sciences, Vol. 10, No. 3, 1970, pp. 279-304.

[10] M. B. Oldstone and F. J. Dixon, "Immunohistochemical
Study of Allergic Encephalomyelitis," American Journal of Pathology, Vol. 52, No. 2, 1968, pp. 251-263.

[11] S. D. Miller, C. L. Vanderlugt, W. S. Begolka, W. Pao, R. L. Yauch, K. L. Neville, Y. Katz-Levy, A. Carrizosa and B. S. Kim, "Persistent Infection with Theiler's Virus Leads to CNS Autoimmunity via Epitope Spreading," Nature Medicine, Vol. 3, No. 10, 1997, pp. 1133-1136. doi:10.1038/nm1097-1133

[12] V. Agnello, "Complement Deficiency States," Medicine, Vol. 57, No. 1, 1987, pp. 1-23.

[13] D. T. Fearon, "Structure and Functions of Compliment," In: M. Z. Ataasi, C. J. Vanoss and D. R. Absolon, Eds., Molecular Immunology, Marcel Dekker, Inc., New York, 1987, p. 511.

[14] J. E. Valanakis, "The Human Complement System," Journal of Oral Pathology, Vol. 4, No. 4, 1975, pp. 195221. doi:10.1111/j.1600-0714.1975.tb01742.x

[15] J. H. Stein, “Complement Measurement," In: S. Puddy, Ed., Internal Medicine, 2nd Edition, Little Brown and Company, Boston, Toranto, 1987, p. 1184.

[16] R. A. Fishman, "Cerebrospinal Fluid in Disorders of the Nervous System," W.B. Sounders, Philadelphaia, London, Toranto, 1980, pp. 95-107.

[17] T. C. Milica, V. Brinar, M. Pauro, Ž. Vogrine and N. Stambuk, "Cerebrospinal Fluid Complement Activation in Neurological Diseases," Journal of the Neurological Sciences, Vol. 154, No. 2, 1998, pp. 173-181. doi:10.1016/S0022-510X(97)00225-6

[18] P. T. Golwmbek, "Immunomodulation of Epilepsy," In: J. M. Rho, R. Sankar and J. E. Cavazos., Eds., Epilepsy, Scientific Foundations of Clinical Practice, Marcel Dekker, Inc., New York, 2004, pp. 299-317.

[19] P. A. Bouma, "Determining the Prognosis of Child Hood Epilepsies by Establishing Immune Abnormalities," Clinical Neurology and Neurosurgery, Vol. 94, No. S, 1992, pp. 54-56.

[20] Y. P. Gholamali, S. Izadi and A. Ghaderi, "Immunological Correlates of Adult Onset Idiopathic Generalized Tonic-Clonic Epilepsy before and after Sodiuurm Valproate Treatment," Iranian Journal of Immunology, Vol. 1, No. 2, 2004, pp. 105-110.

[21] G. M. V. E. Baziel, W. O. Renier, C. M. Weemaes, F. J. Gabreels and H. Meinardi, "Immunoglobulin Treatment in Epilepsy. A Review of the Literature," Epilepsy Research, Vol. 19, No. 3, 1994, pp. 181-190. doi:10.1016/0920-1211(94)90061-2

[22] J. Savory and M. G. Heintges, "Cerebrospinal Fluid Levels of IgG, IgA and IgM in Neurological Diseases," Neurology, Vol. 23, No. 9, 1973, pp. 953-958. doi:10.1212/WNL.23.9.953

[23] M. Masi, P. Paolucci, P. Perocco and C. Franceschi, "Immunosupression by Phenytion," The Lancet, Vol. 307, No. 7964, 1976, pp. 860-860. doi:10.1016/S0140-6736(76)90511-0

[24] M. Bassanini, A. Baez and J. Sotelo, "Immunoglobulins in Epilepsy," Journal of the Neurological Sciences, Vol. 56, No. 2-3, 1982, pp. 275-281. doi:10.1016/0022-510X(82)90148-4 
[25] E. A. Walker, "Allergic Phenomena as Basicmechanisms of the Epilepsies," In: H. H. Jansper, A. A. Ward Jr. and A. Pope, Eds., Basic Mechanisms of Epilepsies, Churchill, London, Boston, 1969, p. 812.

[26] G. Ettlinger and M. B. Lowrie, "An Immunological Factor in Epilepsy," Lancet, Vol. 307, No. 7974, 1976, p. 1386. doi:10.1016/S0140-6736(76)93031-2

[27] A. Amman and R. Hong, "Selective IgG Deficiency," In: E. R. Stiehm and V. A., Fulginiti Eds., Immunological Disorders in Infants and Children, W.B. Saunders, Co., Philadelphia, 1973, pp. 199-214.

[28] B. N. Slavin, G. M. Fenton, M. Laundry and E. H. Reynolds, "Serum Immunoglobulin in Epilepsy," Journal of the Neurological Sciences, Vol. 23, No. 3, 1974, pp. 353357. doi:10.1016/0022-510X(74)90153-1

[29] J. Seager, J. Wilson, D. L. Jamison, A. R. Hayward and J. F. Soothill, "IgA Deficeiency, Epilepsy, and Phenytoin Treatment," Lancet, Vol. 306, No. 7936, 1975, pp. 632635. doi:10.1016/S0140-6736(75)90115-4

[30] P. J. Grob and G. E. Herold, "Immunological Abnormalities and Hydantoins," British Medical Journal, Vol. 2, No. 5813, 1972, pp. 561-563. doi:10.1136/bmj.2.5813.561

[31] A. J. Amman and R. Hong, "Selective IgA Deficiency: Presentation of 30 Cases and a Review of the Literature," Medicine, Vol. 50, No. 3, 1971, pp. 223-236. doi:10.1097/00005792-197105000-00004

[32] S. Yabuki and K. Nakaya, "Immunoglobulin Abnormalities in Epileptic Patients Treated with Diphenylhydantion," Folia Psychiatrica et Neurologica Japonica, Vol. 30, No. 2, 1976, pp. 93-109.

[33] M. Allansmith, B. Wymer and G. Prieto, "Repeated Immunoglobulin Determinations in 15 Individuals over a Six Month Period," Journal of Allergy, Vol. 37, No. 2, 1966, p. 114.

[34] P. Anderson and L. Moseklide, "Immunoglobulin Levels and Autoantibodies in Epileptics on Long-Term Anticonvulsant Therapy," Acta Medica Scandinavica, Vol. 201, No. 1-2, 1977, pp. 69-74.

[35] H. Matsuoka, J. Okada, T. Takashashi, M. Matsuoka, C. Sato and S. Toorii, "Immunological Study of IgA Deficiency during Anticonvulsant Therapy in Epileptic Patients," Clinical \& Experimental Immunology, Vol. 53, No. 2, 1983, pp. 423-428.

[36] R. A. Shakir, P. O. Behan, H. Dick and D. G. Lambie, "Metabolism of Immunoglobulin A, Lymphocyte Function, and Histocompatibility Antigens in Patients on Anticonvulsants," Journal of Neurology, Neurosurgery \& Psychiatry, Vol. 41, No. 4, 1978, pp. 307-311. doi:10.1136/jnnp.41.4.307

[37] U. K. Dashora, A. Pangariya and B. M. Sharma, "Immunoglobulin abnormalities in epileptics," Journal of Indian Medical Association, Vol. 84, No. 2, 1986, pp. 66-67.

[38] J. A. Aarli and A. Fontana, "Immunological Aspects of Epilepsy," Epilepsia, Vol. 21, No. 5, 1980, pp. 451-457. doi:10.1111/j.1528-1157.1980.tb04295.x

[39] J. A. Aarli, "Immunological Aspects of Epilepsy," Brain \& Development, Vol. 15, No. 1, 1993, pp. 41-49. doi:10.1016/0387-7604(93)90005-S
[40] H. K. Al-Hakeim, "Serm Cortisol Immunoglobulins and Some Complements among Depressed Patients," Indian Journal of Clinical Biochemistry, Vol. 23, No. 1, 2008, pp. 76-80. doi:10.1007/s12291-008-0018-2

[41] B. R. Mirdha, "Status of Toxoplasma Gondii in the Etiology of Epilepsy," Journal of Pediatric Neurology, Vol. 1, No. 2, 2003, pp. 95-98.

[42] D. Riddoch and R. A. Thompson, "Immunoglobulin Levels in the Cerebrospinal Fluid," British Medical Journal, Vol. 1, No. 5693, 1970, pp. 396-399. doi:10.1136/bmj.1.5693.396

[43] P. Mc. Callenbach, C. M. J.-V. Der Zijde, A. T. Geerts, W. F. Arts, C. A. Van Donselaar, A. C. Peters, H. Stroink, O. F. Brouwer and M. J. Van Tol, "Immunoglobulins in Children with Epilepsy: The Dutch Study of Epilepsy in Childhood," Clinical \& Experimental Immunology, Vol. 132, No. 1, 2003, pp. 144-151.

[44] M. Ashrafi, S. A. Hosseini, S. Abolmaali, M. Biglari, R. Aziz, M. Farghadan, A. Samadian, S. Saghafi, H. Mombeini, N. Saladjegheh, N. Rezaei and A. AghaMohammed, "Effect of Anti-Epiteptic Drugs on Serum Immunoglobulin Levels in Children," Acta Neurologica Belgica, Vol. 110, No. 1, 2010, pp. 65-70.

[45] S. Bostantjopoulou, O. Hatzizisi, O. Argyropoulou, S. Andreadis, K. Deligiannis, M. Kantaropoulou, A. Kazis, G. Kyrazis and K. Routsonis, "Immunological Parameters in Patients with Epilepsy," Functional Neurology, Vol. 9, No. 1, 1994, pp. 11-15.

[46] F. De Ponti, S. Lecchini, M. Cosentino, C. M. Castelletti, A. Malesci and G. M. Frigo, "Immunological Adverse Effects of Anticonvulsant, What Is Their Clinical Relevance?" Drug Safety, Vol. 8, No. 3, 1993, pp. 235-250. doi:10.2165/00002018-199308030-00005

[47] A. Basta-Kaim, B. Budziszewska and W. Lason, "Effects of Anti Epileptic Drugs on Immune System," Przeglad Lekarski, Vol. 65, No. 11, 2008, pp. 799-802.

[48] J. Ranua, K. Luoma, A. Auvinen, J. Peltola, A. M. Haapala, J. Raitanen and J. Isojarvi, "Serum IgA, IgG, and IgM, Concentrations in Patients with Epilepsy and Matched Controls: A Cohort-Based Cross Sectional Study," Epilepsy \& Behavior, Vol. 6, No. 2, 2005, pp. 191-195. doi:10.1016/j.yebeh.2004.11.017

[49] E. J. Bardana Jr., J. D. Gabourel, G. H. Davies and S. Craig, "Effects of Phenytoin on Man's Immunity. Evaluation of Changes in Serum Immunoglobulins, Complement, and Antinuclear Antibody," American Journal of Medicine, Vol. 74, No. 2, 1983, pp. 289-296.

[50] A. Vezzani, "Innate Immunity and Inflammation in Temporal Lobe Epilepsy: New Emphasis on the Role of Complement Activation," Epilepsy Currents, Vol. 8, No. 3, 2008, pp. 75-77. doi:10.1111/j.1535-7511.2008.00243.x

[51] E. Aronica, K. Boer, E. A. Van Vliet, S. Redeker, J. C. Baayen, W. G. M. Spliet, P. C. Van Rijen, D. Troost, F. H. Lopes da Silva, W. J. Wadman and J. A. Goter, "Complement Activation in Experimental and Human Temporal Lobe Epilepsy," Neurobiology of Disease, Vol. 26, No. 3, 2007, pp. 497-511. doi:10.1016/j.nbd.2007.01.015

[52] P. Price and M. L. Cuzner, "Cerebrospinal Fluids Complement Proteins in Neurological Disease," Journal of the 
Neurological Sciences, Vol. 46, No. 1, 1980, pp. 49-54. doi:10.1016/0022-510X(80)90042-8

[53] N. Basaran, F. Hincal, E. Kansu and A. Ciger, "Humoral and Cellular Immune Parameters in Untreated and Phenytoin or Carbamazepine Treated Epileptic Patients," International Journal of Immunopathology and Pharmacology, Vol. 16, No. 12, 1994, pp. 1071-1077.

[54] B. Oettinger and K. Richter, "Antiepileptic Drug Levels and Side Effects in Man," Monoger Neurological Science, Vol. 5, 1980, pp. 240-244.

[55] N. E. Gilhus and J. A. Aarli, "Respiratory Disease and Nasal Immunoglobulin Concentrations in Phenytiontreated Epileptic Patients," Acta Neurologica Scandinavica, Vol. 63, No. 1, 1981, pp. 34-43. doi:10.1111/j.1600-0404.1981.tb00746.x

[56] G. Mancini, A. O. Carbonara and J. F. Heremans, "Immunochemical Quantitation of Antigens by Single Radical Immunodiffusion," Immunochemistry, Vol. 2, No. 3, 1965, pp. 235-254.

[57] R. Olsson, "Plasma Proteins in Patients on Long Term Anti Epilepthic Treatment," Clinical Chemistry, Vol. 29,
No. 4, 1983, pp. 728-730.

[58] S. Moustafa, A. Osama, A. Saad, S. El-Seed and N. Moustafa, "Immunotoxicity of Chronic Phenytoin Administration in Epileptic Patients," Egyptian Journal of Neurology, Psychiatry and Neurosurgery, Vol. 43, No. 1, 2006, pp. 435-441.

[59] S. Kumar, "Medico-Physical Studies on Epilepsy and Other Neurological Disorders," Ph.D Thesis, University of Delhi, Delhi, 1989.

[60] T. L. Moore, R. E. Ryan Jr., D. A. Pohl and S. T. Roodman and R. E. Sr. Ryan, "Immunoglobulin, Complement, and Immune Complex Levels during a Migrane Attack," Headache: The Journal of Headache and Face Pain, Vol. 20, No. 1, 1980, pp. 9-12.

[61] G. D. A. Lord and J. W. Duchworth, "Immunoglobulin and Complement Studies in Migrane," Headache: The Journal of Head and Face Pain, Vol. 17, No. 4, 1977, pp. 163-168. doi:10.1111/i.1526-4610.1977.hed1704163.x

[62] T. Granata, H. Cross, W. Theodore and G. Avanzini, "Immune-Mediated Epilepsies," Epilepsia, Vol. 52, No. Suppl 3, 2001, pp. 5-11. 